\title{
Toxicity Issues Related to Biomedical Applications of Carbon Nanotubes
}

\author{
Sapna Jain ${ }^{1}$, Shree R. Singh ${ }^{1}$ and Shreekumar Pillai ${ }^{2 *}$
}

${ }^{1}$ Center for NanoBiotechnology Research, Alabama State University, Montgomery, Al-36104, USA

${ }^{2}$ Department of Math and Science, Alabama State University, P.O. Box 271, 915 S Jackson Street, Montgomery, AL 36101-0271, USA

\begin{abstract}
Carbon Nanotubes (CNTs) have emerged as a potential candidate for application in targeted drug delivery, cancer treatment, gene therapy and diagnostics. This review critically evaluates the biomedical potential of CNTs, and possible toxicological implications. Success of CNTs in other fields has not yet been translated to the biomedical field due to the lack of consistent data on toxicity, variation of toxicity due to characteristics such as shape and size along with the method of preparation, and limited control over functionalized CNTs behavior. Thus there is a lack of a predictable toxicity pattern of CNTs. This review summarizes the key findings on the toxicity of CNTs and the role of functionalization with hydrophilic moieties to reduce their toxicity, and increase cell penetrability for drug delivery and gene therapy applications. Caution is urged when handling this 'wonder material' but the immense potential for its commercial utilization and clinical trials infuses hope for future biomedical applications.
\end{abstract}

Keywords: Carbon nanotubes; Toxicity; Biomedical applications

\section{Introduction}

Nanotechnology is the study of materials ranging in size from 0.1 $100 \mathrm{~nm}$. Nanoscale materials have been categorized in different ways by many popular official sources. For example, the National Academies categorized nanoscale materials into four groups: (1) the metal oxides (2) nanoclays (3) nanotubes and (4) quantum dots [1]. The US Environmental protection agency (EPA) has classified them as (1) carbon-based materials (2) metal based materials (3) dendrimers (4) composites including nanoclays. Among these nanomaterials, CNTs have generated significant interest since Iijima [2] discovered CNTs while synthesizing fullerenes in 1991. These unique structures possess tremendous strength, very high aspect ratio and excellent thermal and electrical conductivity. Thus CNTs have found commercial applications in electronics [3,4] optics [5], materials science [6,7] and architecture [8]. More recently, CNTs have been used in biomedical engineering, tissue engineering, drug delivery, gene therapy and biosensors. However, the successful commercial application of CNTs in medicine may depend largely upon their toxicity for humans, animals and the environment. Chemical modification of CNTs in order to make them more biocompatible is one of the major areas of current research [9]. The intent of this review is to highlight various toxicity issues, including the toxicity of CNTs at the cellular, genetic and systemic level. The paper critically evaluates the ways to overcome toxicity in order to exploit the complete potential of CNTs as an accessory tool for various biomedical applications and allied fields. It also discusses the regulatory concerns, risk of accidental exposure and the future market potential of CNTs.

\section{Classification and general properties of CNTs}

CNTs are long chains of carbon held together with each carbon atom bonded to three neighbouring carbon atoms forming $\mathrm{sp}^{2}$ hybridized carbon. Since $\mathrm{sp}^{2}$ hybridization is stronger than the $\mathrm{sp}^{3}$ hybridization found in diamond, CNTs have unique strength. From an atomic point of view, a nanotube can be divided into two parts; the side-wall and the end cap. The end caps can be considered as hemispherical fullerenes, curved in 2D and the side wall contains less distorted carbon atoms and is curved in 1D. CNTs are mainly classified into two types depending upon the structure: (1) Single Walled Carbon Nanotubes (SWCNTs) (2) Multiwalled Carbon Nanotubes (MWCNTs). SWCNTs are formed when just one graphene sheet rolls up to form a tubular structure, while more than one concentric graphene sheets creates MWCNTs [10]. The width of CNTs ranges from a few to tens of nanometers, but their length ranges from less than a micrometer to few millimeters. CNTs can be classified as Carbon Nanohorns (CNHs), nanobuds and nanotorus, depending upon their shape [11] .

\section{Applications of CNTs}

CNTs have been exploited for applications in drug delivery, gene therapy, cancer therapy, vaccine delivery, imaging and diagnostics. Out of the several applications, a few are discussed in more detail below.

CNTs in controlled and targeted drug delivery: CNTs have been used to improve the pharmacological and therapeutic profile of a drug molecule. The ability of functionalized CNT to penetrate into cells has been exploited for the delivery of small drug molecules in a controlled manner [12,13]. CNTs can be simultaneously functionalized with moieties for targeting, imaging as well as therapy [14]. The outer surface of the CNTs is modified to improve its solubility and biocompatibility and the inner hollow core is used for insertion of the drugs [15]. A multi-functionalization strategy was used to functionalize CNTs with a fluorescent probe for tracking after cellular uptake and an antibiotic moiety, amphotericin B was covalently linked for its controlled delivery without any toxic effects $[16,17]$. The use of CNTs is widely accepted for the treatment of cancer as they are capable of targeting malignant cells because of better uptake by a specific population of malignant cells without affecting the healthy cells and rapid elimination from the body following systemic administration (Figure 1). Prato and group also suggested that the most important factors governing the fate of CNTs inside the body are their shape and size. Since they are nanosize, they easily escape cellular opsonization or phagocytosis

*Corresponding author: Shreekumar Pillai, Department of Math and Science, Alabama State University, P.O. Box 271, 915 S Jackson Street, Montgomery, AL 36101-0271, USA, Tel: 334-229-7501; E-mail: spillai@alasu.edu

Received May 08, 2012; Accepted May 25, 2012; Published June 01, 2012

Citation: Jain S, Singh SR, Pillai S (2012) Toxicity Issues Related to Biomedical Applications of Carbon Nanotubes. J Nanomed Nanotechol 3:140. doi:10.4172/2157-7439.1000140

Copyright: (c) 2012 Jain S, et al. This is an open-access article distributed under the terms of the Creative Commons Attribution License, which permits unrestricted use, distribution, and reproduction in any medium, provided the original author and source are credited. 
as a harmful foreign intruder [18]. Delivery of drug to tumor site is through Enhanced Permeability and Retention (EPR) effect [19]. In healthy tissues, the pore size of blood vessels is much smaller $(2-6 \mathrm{~nm})$ as compared to tumor tissues $(100-800 \mathrm{~nm})$ [20]. Thus, nanoparticles ranging from $100-700 \mathrm{~nm}$ cannot penetrate the healthy blood vessels but easily penetrate inside the tumor blood vessels and accumulate at the tumor site. Poly Ethylene Glycol (PEG) functionalized CNTs can be conjugated with a cancer chemotherapy drug, Paclitaxel (PTX) via the amide bond formation between the PEG chains and paclitaxel and effectively inhibit cancer growth in mice [21]. PEG was used to functionalize SWCNTs as the SWCNT-PEG complex did not cause any toxicity in mice over several months after intravenous injection. The SWCNT-PTX conjugated were retained in blood for longer duration $(81.4 \pm 7.4 \mathrm{~min})$ than taxol (clinical drug formulation of PTX) $(18.8 \pm$ $1.5 \mathrm{~min})$ and PTX coated with PEG $(22.8 \pm 1.0 \mathrm{~min})$. Thus enhanced EPR effect, prolonged circulation, better delivery efficacy and tumor inhibition of the drug is achieved by SWCNT-PTX ( $5 \mathrm{mg} / \mathrm{kg}$ PTX) for the $4 \mathrm{~T} 1$ tumor model which is known to be resistant to PTX treatments.

CNTs as a non viral gene delivery system: Ammonium functionalized CNTs are exploited for their application as a delivery vector for gene-encoding nucleic acids. Stable complexes can be formed from cationic CNTs and plasmid DNA, which are demonstrated to enhance gene therapeutic capacity in comparison to DNA alone [18] (Figure 2). The gene expression was upregulated 10 times higher than those achieved with DNA alone [22]. Ammonium functionalized SWCNTs have been used to mediate the delivery of Telomerase Reverse Transcriptase (TERT) siRNA into tumor cells. The release of siRNA silences the targeted TERT gene that is critical for the development and growth of tumors. Administering the SWCNTTERT-siRNA complex in mice bearing the Lewis carcinoma tumor, resulted in suppression of the cancer cell growth and reduction of average tumor weight [23]. Ammonium functionalized SWCNTs were complexed with double stranded DNA and multifunctionalized with phospholipid-PEG containing a tumor targeting moiety (folic acid) [20]. Cationically functionalized CNTs with polyethyleneimine and pyridinium moieties (CNT-PEI and CNT-pyridinium) have been studied for siRNA delivery. Both functionalized CNTs complexed with siRNA showed reduced toxicity and increased silencing activity $[24,25]$. The ammonium functionalized SWCNT have been employed

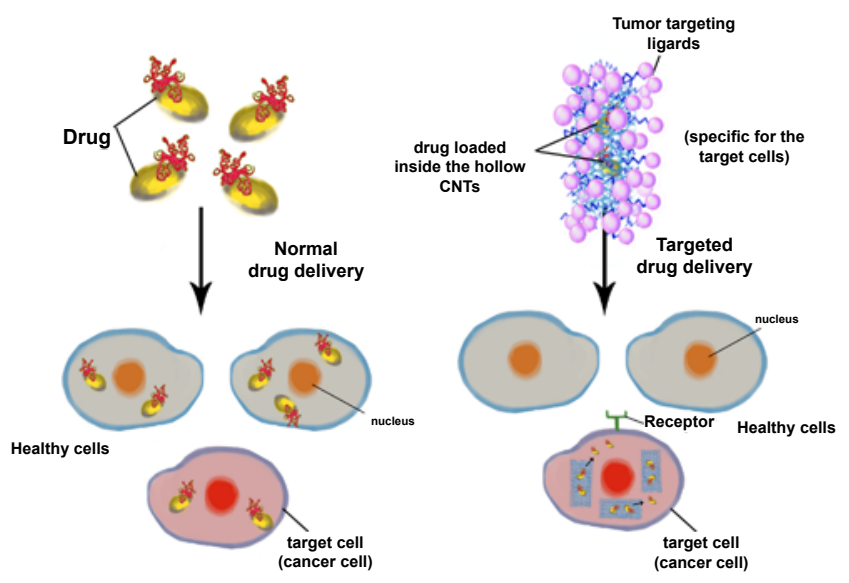

Figure 1: Efficient targeted drug delivery using CNTs versus inefficient nontargeted drug delivery.

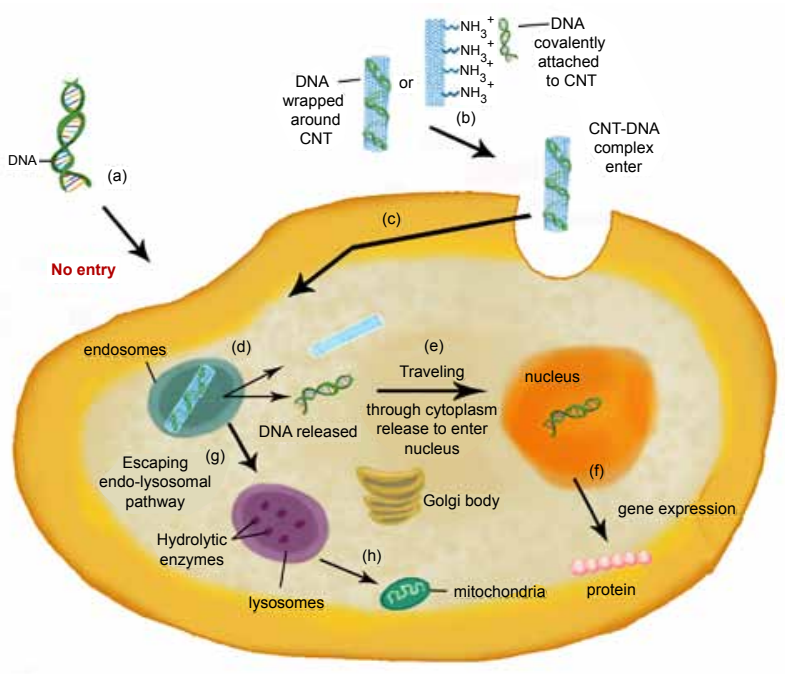

Figure 2: Gene delivery by CNTs (a) Plasmid DNA (DNA) by itself is unable to penetrate the cell membrane (b) DNA is either covalently or non-covalently attached to CNTs (c) DNA conjugated CNTs gain entry inside the cell (d) DNA released in the cytoplasm (e) DNA travels through cytoplasm to enter the nucleus (f) gene expressed (g) DNA-CNT complex escapes from endolysosomal pathway and subsequent degradation by hydrolytic enzymes and ( $h$ ) finally goes to mitochondria.

for the delivery of temolerase reverse ranscriptase (TERT) siRNA into tumor cells. These functionalized CNTs released the siRNA to silence the targeted TERT gene, which is critical for the development and growth of the tumors. It was observed that the treatment cancer cells with SWCNT-TERT-siRNA complexes resulted in suppression of the cancer cells growth. It was concluded that functionalization of CNTs might act as a key factor in obtaining an efficient nontoxic CNT-based delivery system [21].

CNTs in diagnostics: CNTs can be useful in determining the cause of disease (pathogen detection), level of disease progression and pathological condition by acting as artificial smart devices as nanosensors and nanorobots [11]. CNT-based biosensor devices have applications in detecting biological disorders such as autoimmune diseases by exploiting the fact that it is able to detect antigens associated with such diseases. These sensors have also been used during space missions as these nano-devices can be administered through skin $[26,27]$. CNT based piezoelectric pressure sensor has the capability of detecting the changes in resistance in SWCNT as the pressure is applied. This can find applications in blood pressure monitoring $[28,29]$. SWCNTs were used to modify glassy carbon electrodes for detection of DNA from Salmonella enterica serover Typhimurium using electrochemical impedimetric sensing technique. Electrode surface was coated with single stranded DNA (ssDNA) functionalized SWCNTs. The target DNA sensing was accomplished by measuring the change in the impedance and charge transfer resistance before and after the complementary ssDNA binding takes place [30]. The immunological sensor based on functionalized gold electrode allowed rabies antigen detection [31]. The specific rabies antibodies were immobilized onto the functionalized gold microelectrode and the interaction of the antibody with specific antigen was measured with low limit detection with a good reproducibility with impedance spectroscopy. Electrochemical immunosensors using SWCNTs conjugated with antibody for highly sensitive detection of a cancer biomarker in serum and tissue lysate have been reported [32]. Amplified sensitivity was achieved by 
conjugation of SWCNTs with horse radish peroxidase (HRP) labels and secondary antibodies $(\mathrm{Ab}(2))$ at a high $\mathrm{HRP} / \mathrm{Ab}(2)$ ratio. This way, detection of low limit $(4 \mathrm{pg} / \mathrm{ml})$ of prostate specific antigen (PSA) in $10 \mu \mathrm{l}$ of undiluted calf serum was achieved. This immunosensor holds promise for clinical screening of cancer biomarker and point-of-care diagnostics.

Current toxicological knowledge: The broad and increasing range of the biological applications of CNTs and other nanoparticles has exposed humans, animals and the environment to these nanoparticles $[32,33]$. Thus it has become imperative to evaluate the biocompatibility and toxicity of CNTs on both human health and the environment. As compared to bulk materials, nanomaterials could have a range of effects due to their increased surface area to size ratio, which makes them more reactive and potentially more harmful [34-37]. For example, they may not be detected by the normal phagocytic defenses allowing them to gain access to the blood or the nervous system. CNTs could act like haptens to modify protein structures altering their function or rendering them antigenic, raising the potential for autoimmune effects $[11,38-40]$. Several studies $[41,42]$ on the toxic effects of CNTs suggest different mechanisms as to how nanoparticles induce toxic effects. Some of the proposed mechanisms include: (i) Reduction in size leads to increase in their relative surface area, which allows for a greater contact area with cellular membranes, as well as a greater capacity for absorption and transportation of toxic substances (ii) Different electronic properties of nanoparticles as compared to their bulk form could be a potential contributing factor [40]. Reduction of size to the nano scale creates discontinuous crystal planes increasing the number of structural defects and disrupting the well-structured electronic configuration and altering their electronic properties [4345] (iii) Different surface chemistry of nanoparticles which make them hydrophobic or hydrophilic, lyophilic or lyophobic, catalytically active or inactive [43-45] (iv)The electron donor or acceptor active sites on the surface of the nanoparticles can react with molecular dioxygen, forming super oxide radicals $\left(\mathrm{O}_{2}^{-}\right)$, which through dismutation or fenton chemistry can generate additional reactive oxygen species (ROS) [46] (v) Specific transport properties are due to differences in shape, aggregation, surface functionalization, and solubility of nanoparticles $[47,48]$. Most of these properties can be controlled by adopting different manufacturing processes, or altering physical conditions of the process such as temperature, pressure, catalyst, dispersion techniques, or choice of the dispersant to name a few.

Toxicity at the level of synthesis: One of the major causes of CNTs toxicity arises from the catalyst residues left after their production. Synthesis of CNTs involves the use of metal catalysts like $\mathrm{Fe}, \mathrm{Ni}, \mathrm{Co}$, As, Mo etc. [49] that are quite toxic by themselves. These elements if not removed during the purification step, tend to catalyze oxidative processes by free radical generation. The ROS thus generated cause oxidative damage to cells and membranes. Catalysts also act by interfering with the immune system at the cellular level. When CNTs are engulfed by macrophages, Nicotinamide adenine dinucleotide phosphate-oxidase (NADPH-oxidase) inside the cell produces superoxides $\left(\mathrm{O}_{2}{ }^{-}\right)$. Fe based catalysts react with these superoxides to form hydroxyl ions, resulting in oxidative stress and damage at the molecular level [39].

Post fabrication treatment induced toxicity: It has been noted that purification steps like oxidation by chemical etching greatly affect CNTs toxicity. MWCNTs subjected to oxidation with nitric acid were more toxic to T-lymphocytes than their impure counterparts [50]. It was noted that CNTs with added carbonyl (CO), carboxylic (COOH), and hydroxyl (-OH) groups are more toxic than their pristine counterparts [51]. The toxic effects of CNTs are negligible at low concentrations (5 $\mu \mathrm{g}-10 \mu \mathrm{g})$ but in order to use higher concentrations $(50 \mu \mathrm{g}-500 \mu \mathrm{g})$ highest purity CNTs have to be used which minimizes the toxic effects of residual catalysts or surface oxidation [52].

Physical attributes of CNTs responsible for toxicity: The physical attributes of CNTs, like fiber shape, length and the aggregation status can also influence the immunological responses and their local deposition in tissues [53]. The shape and length of CNTs can determine the internalization of CNT by macrophages and hence the immune response. Shorter CNTs were found to be less toxic than the longer CNTs. Shorter length CNTs when injected subcutaneously in rat were found in the cytosol of the macrophages after 4 weeks, but longer CNTs were found to be free floating and causing inflammation [54] confirmed that the toxicity of MWCNTs was length dependent and comparable with that of asbestos toxicity. Abdominal cavities of rats were injected with MWCNTs and asbestos fibers. After $24 \mathrm{~h}$ of exposure increased immune response was observed, and after 7 days of exposure, granuloma formation was observed in both cases. They named the increased immune response due to MWCNTs exposure as "frustrated phagocytosis" wherein macrophages were unable to engulf long CNTs mainly because of their length.

Surface area and surface chemistry also influence toxicity of a nanoparticle. In one study, five carbon based materials, graphite, SWCNTs, MWCNTs, active carbon, and carbon black were tested for their toxicity on fibroblast cells $[55,56]$. SWCNTs were found to be most toxic because they had the lowest surface area. It was found that hydrophobic SWCNTs with low surface area induce enhanced toxic effects. CNTs influenced extracellular matrix protein signaling that resulted in deformation of cell membranes, and displacement of cell organelles finally leading to cell death. When two nanoparticles have comparable surface area, toxicity depends on their surface chemistry [57]. It was observed that unrefined SWCNTs were more toxic than the refined SWCNTs. This was because the unrefined SWCNTs agglomerated and their surface area decreased, and lower surface area resulted in higher toxicity. Whereas refined SWCNTs remained dispersed and thus were less toxic [58].

\section{Mechanism of uptake of CNTs}

Several groups have worked towards establishing the uptake mechanism of CNTs inside the lipid membrane bound cell and their influence in causing toxicity. Many studies have shown that functionalized CNTs are able to cross the cell membrane $[59,60]$. There are five methods of internalization of CNTs inside the cells, phagocytosis, macro-pinocytosis, clathrin-mediated endocytosis, caveolin mediated path-ways, and clathrin/caveolin independent pathways [61]. So far, the two most widely accepted mechanisms of CNTs internalization proposed are (i) endocytosis/phagocytosis and (ii) nanopenetration.

\section{Active internalization of CNTs via endocytosis}

Several studies have shown that the mechanism of internalization of CNTs is by endocytosis $[60,62]$. It was observed that fluorescently labeled SWCNTs conjugated with protein or DNA were able to enter HL60 cells and HeLa cells after $1 \mathrm{~h}$ of incubation at $37^{\circ} \mathrm{C}$. By contrast, protein and DNA alone were not located inside the cells under the same experimental conditions [63]. Low energy, low temperature or depletion of ATP (adenosine triphosphate) inhibits the endocytosis process. Cellular uptake of CNTs was reduced at lower temperature 
$\left(4^{\circ} \mathrm{C}\right)$ in the cells pre-incubated with ATP inhibitors like sodium azide [64]. CNTs can also be internalized by clathrin mediated endocytosis. When CNTs come in contact with cells, clathrin-coated pits are formed under the plasma membrane and each pit then forms a vesicle inside the cell [62]. Length of the CNTs influences the internalization process. Shorter CNTs are able to internalize more readily than the larger ones [65]. Cellular uptake of CNTs was greatly reduced when cells were grown in media rich in $\mathrm{K}^{+}$and sucrose, that are known to inhibit the formation of clathrin-coated vesicles in the cell membrane [66,67].

\section{Passive internalization of CNTs via nanopenetration}

Nanopenetration is an energy independent process, where nanoparticles diffuse passively through cellular membranes. Studies have indicated that CNTs more likely penetrate inside the cell passively just as a nano-needle would diffuse across the cell membrane $[68,69]$. Functionalized CNTs can cross cellular barriers by altering their interaction with cells and alteration of intracellular transport kinetics of the functionalized CNTs. To study the mechanism of uptake, SWCNTs and MWCNTs were functionalized by several moities including ammonium groups, antibodies, fluorescent tags, anticancer drugs and antibiotics. All these functionalized CNTs were internalized even in the presence of endocytosis- inhibitors [70]. FITClabeled CNTs were also tracked in human T36 cells and murine 3T3 fibroblasts, showing that the internalization of CNTs was not hindered by lowering the temperature or by the presence of sodium azide which inhibits endocytosis [71].

The diffusion mechanism of functionalized CNTs across the membrane is not completely understood. According to one view [72-74] the perpendicular orientation of CNTs to cell membranes leads them to behave like nano-syringes and diffuse inside the cells. A two-step process of diffusion has been suggested. CNTs are first 'accommodated' onto the cell membrane and then oriented in a way to achieve a 'transmembrane configuration'. Hydrophilic and static charge interactions between the CNTs and the lipid bilayer plays a lead role in internalization of the CNTs [75] .

So far no conclusions can be drawn in support of just one mechanism that best describes the internalization of CNTs inside the cells. In fact, the arguments for both pathways look quite convincing. Nevertheless several factors like type of functionalization, density and the charge of the ligand, shape, size, agglomeration and hydrophobic and hydrophilic interactions between cell surfaces and CNTs will all play an important role in determining the CNTs internalization mechanism. CNTs surface is hydrophobic but by functionalization with hydrophilic groups, they can be made hydrophilic. Thus, their interaction with the hydrophilic regions of the cell membrane will greatly influence the cellular uptake of CNT [56].

\section{Mechanism of CNTs toxicity}

CNT exposed cells undergo oxidative stress because of induction of oxidants and toxic enzymes. Higher level of oxidative stress leads to inflammation and cytotoxicity. Protein kinase and nuclear factorKappa B (NF-kB) signaling pathways regulate proinflammatory cytokines and apoptosis in response to oxidative stress. The decrease in cell viability and elevated levels of the proinflammatory cytokines Interleukin-8(IL-8) and IL-1 $\beta$ indicates that MWCNTs can initiate an inflammatory response in Human Keratinocytes (HEKs) at $0.4 \mathrm{mg} / \mathrm{ml}$ dose [76]. Apoptosis could result from mitochondrial disruption and release of pro-apoptotic factors [77]. Several mechanisms may underlie the toxicity of CNTs as outlined below.

\section{Free radical formation}

The main cause of toxicity is related to oxidative stress by free radical formation. These excess free radicals oxidize lipids, protein, and DNA. Oxidative stress may upregulate redox sensitive transcription factors, activator protein-1 and kinases that cause inflammatory responses. Slow clearance caused due to agglomeration or accumulation of these nanoparticles may produce free radicals, in the organs of Reticulo Endothelial System (RES) making organs like the spleen, kidneys and lungs, soft targets for this oxidative stress [78].

\section{Reactive Oxygen Species (ROS)}

ROS are chemically reactive oxygen containing molecules that are formed as byproducts of the normal metabolism of oxygen. However, the level of ROS may increase due to environmental stress such as exposure to radiation, foreign particles etc. ROS may lead to harmful effects in cells like apoptosis, DNA damage, amino acid oxidation and inactivity of enzymes [79]. Studies have shown that SWCNTs damage DNA, cause changes in the cell cycle and generated apoptotic signals by generating ROS. Most cells grown on media containing CNTs altered the G1 phase of their cell cycle [80]. Wang et al. [78] have determined that apoptosis of PC12 cells was induced by 4 to 5 fold higher concentrations of ROS in cells exposed to SWCNTs $(200 \mu \mathrm{g} /$ $\mathrm{ml}$ ). MWCNTs have been shown to induce ROS in Human Umbilical Vein Endothelial Cells (HUVEC) at $20 \mu \mathrm{g} / \mathrm{ml}$ concentration [81,82].

\section{Increased inflammatory responses}

Poland and group [54] compared inflammatory responses produced by exposing mice to carbon black, asbestos and MWCNTs. While carbon black initiated a normal foreign body response, where the immune system recognized and destroyed foreign particles, MWCNTs and asbestos exposure increased the release of polymorphonuclear leukocytes and protein exudation, indicating an increased inflammatory response. The same group also showed the difference in toxicity levels between short and long MWCNTs. They attributed the increased inflammatory response of long MWCNTs and asbestos to "frustrated phagocytosis" in which the macropghages are unable to engulf the long needle shaped CNTs. By contrast, in another study done on a mouse macrophage RAW 264.7 cell line, CNTs induced ROS related necrosis, apoptosis and chrosomal damage, but do not induce an inflammatory response [83].

\section{Granuloma formation}

Granuloma is a small nodule or a tiny collection of immune cells formed when the immune system attempts to wall off foreign substances, but is not able to eliminate them. CNTs as well as asbestos both were found to cause granulomas in mice exposed for 7 days [54]. Intratracheal instillation of SWCNTs (diameter ranging from 0.7-0-1.5 $\mathrm{nm}$ ) in the lungs of rats lead to blockage of the large airways as a result of the formation of granulomas, with $15 \%$ mortality within one day [84].

\section{Apoptosis}

SWCNTs caused the maximum apoptosis of five carbon-based nanomaterials that were tested including SWCNTs and MWCNTs for toxicity on human fibroblast cells [85]. These researchers hypothesized that dispersed, hydrophobic materials with small surface area displayed increased toxicity. They proposed that the mechanism of toxicity due to CNTs was due to extracellular matrix protein signaling resulting in changes to the cell skeleton and the subsequent displacement of organelles, resulting in membrane deformation and finally apoptosis. 
There is evidence showing that CNTs caused apoptosis in several cell types including T- lymphocytes and HEK293 cells. Genes associated with apoptosis (p16, bax, hrk, bak1, p53, p57FGFR2, TGF beta receptor1 (TGFbetaR1) and TNFAIP2) were up-regulated by CNTs [85]. Other studies also indicated the upregulation of genes responsible for apoptosis [86]. The unfunctionalized (UP-CNTs), purified (P-CNT), and FITC functionalized (FITC-CNTs) all caused decreased cell viability and increased apoptosis [83] .

\section{Functionalization approaches}

Pristine CNTs have smooth surfaces without any hanging bonds, which makes them chemically inert and insoluble in most organic and inorganic solvents. Thus incompatibility of CNTs with most solvents is one of the major drawbacks for their biomedical applications. There are 2 main methods to increase the solubility of CNTs: one is covalent functionalization (nicknamed as 'defect functionalization'), where CNTs are covalently modified with functional groups on the surface, by chemically decorating their side walls and tips via oxidation to generate carboxylic groups or carboxylated fractions, which can be further chemically modified via amidation or esterification [87-89]. The other is a non-covalent functionalization approach which involves physical absorption of small molecules or polymers onto the surface of CNTs through hydrophobic interactions, $\pi-\pi$ interactions or molecular inclusions [68]. CNT functionalization schemes with the moieties of biological interests that reduce toxicity are shown in the Table 1 .

\section{Covalent modification of CNTs}

The covalent functionalization strategy can be further divided into two main approaches (i) oxidation of CNTs followed by carboxyl based couplings (ii) addition reactions to the sidewalls and tips of CNTs. The oxidative functionalization approach involves the use of strong acid treatment, which opens the tube cap and results in the formation of holes in the side-walls of CNTs [90]. The carboxylic group introduced into the cap and the side-walls enhances the solubility of CNTs in aqueous solution. Further these carboxylated CNTs can be modified via amidation or esterification to link a wide variety of biomolecules like peptides, proteins, nucleic acids and other therapeutic agents. Addition reactions can also be used for the covalent modifications of CNTs. Prato and colleagues developed 1,3-dipolar addition of SWCNTs with azomethine ylides [91]. This strategy was initially used to modify Buckminsterfullerene $\left(\mathrm{C}_{60}\right)$ SWCNTs were suspended in Dimethylformamide (DMF) with an aldehyde and $\mathrm{N}$-substituted glycine derivative, at $30^{\circ} \mathrm{C}$, resulting in the formation of substituted pyrrolidine moieties on the SWCNTs surface. Streptavidin functionalized nanotubes were obtained with improved solubility and were used mainly to visualize the interaction of nanotubes with HL60 cells for 1 hour at $37^{\circ} \mathrm{C}$ [60]. Apart from functionalization at defect sites, various other methods have been adopted to improve solubility of CNTs such as the addition of azomethine ylides, diazonium salts, carbenes, nitrenes, and radicals to SWCNTs. One such approach of direct covalent modification is Diels-Alder cycloaddition using transition metals at enhanced pressure. In order to detect and quantify covalent functionalization, the ratio of intensities of the D-band to the G-band $\left(\mathrm{I}_{\mathrm{D}} / \mathrm{I}_{\mathrm{G}}\right)$ in the Raman spectra was used as a probe. D-band is increased in the functionalized SWCNTs as an indicator of significant conversion of $\mathrm{sp}^{2}$ to $\mathrm{sp}^{3}$ hybridization of carbon atoms in CNTs [92,93]. The benefits of addition reaction modifications are that they are systematic, and predictable chemistry can be achieved by generating pyrrolidine rings on the side walls of CNT. Covalent bonds are strong bonds and easy to control, and they offer the possibility for multi-functionalization of CNTs, for possible use as drugs and other therapeutics carrier.

\section{Non-Covalent modification of CNTs}

This refers to physical adsorption or wrapping of molecules or polymers onto the surface of CNTs without any chemical bonding. The advantage of this type of modification is that it preserves the structure and desired properties of CNTs and at the same time improves its solubility for further applications. There are two main approaches for non-covalent functionalization of CNTs. One is wrapping biomolecules like DNA, RNA around the CNT walls and the other is through $\pi-\pi$ stacking interaction between aromatic rings of the loaded material and $\pi$ electrons of CNTs [68,94-96]. Various aromatic molecules like pyrenes, porphyrins, conjugated polymers, peptides, saccharides, DNA and other biomolecules and surfactants interact with the side walls of CNTs by means of $\pi-\pi$ stacking interactions [90]. Different approaches for functionalization could be used based on the application of CNTs. Covalent chemical reactions allows stable functionalization, improved solubility and biocompatibility of CNT, but CNT properties could be changed as damage is caused to the side walls thereby decreasing the Raman scattering, near-infrared photoluminescence and optical absorbance. Thus, the covalent functionalization approach could be used for the delivery of drugs, genes and other bioactive molecules inside the cells. However, covalent functionalization may not be an ideal approach for sensing and imaging applications. On the other hand, non-covalent functionalization maintains the structural and optical properties of CNTs (Figure 3) and could be effectively used for sensing and imaging purposes.

\section{Functionalization of CNTs for improved biocompatibility}

For biomedical applications, raw hydrophobic CNTs must be functionalized in order to improve solubility and biocompatibility (Table 2). The uptake of SWCNTs in biological systems in vitro (cellular uptake) and in vivo (blood circulation and biodistribution) largely depends on their surface chemistry $[13,97,98]$. Functionalized CNTs with improved solubility and biocompatibility are able to cross cell membranes and successfully transport bioactive molecules like DNA, RNA, drugs and proteins into the targeted cells [99]. In fact in vivo studies in mice have indicated that well functionalized CNTs accumulate in the reticuloendothelial system and are slowly excreted through bile without causing side effects to the mice. Chitosan wrapped CNTs were found to improve dispersion and biocompatibility of CNTs through non-covalent interaction [100]. Non-covalently functionalized SWCNTs with amphiphilic phospholipid-poly ethylene glycol (PLPEG) displayed excellent solubility, biocompatibility and stability in the aqueous phase. The hydrophobic lipid chains of PL-PEG strongly adsorb on to the CNTs surface, whereas the hydrophilic PEG chain improved solubility and biocompatibility of the entire functionalized SWCNT unit $[65,101]$. In another study, carboxylated SWCNTs were covalently conjugated with anti-HER2 chicken IgY antibody for detection and selective destruction of breast cancer cells using NIR radiations. The complex could be potentially used for detection and selective photothermal ablation as well as targeting breast cancer cells without the need of internalization by the cells. Thus this new strategy utilizes unique intrinsic properties of HER2 IgY-SWCNT complexes for both cancer detection and therapy [102].

An investigation has been conducted on how structure and type of functionalization of SWCNTs and MWCNTs affects immunotoxicity in Oncorhynchus mykiss, an aquatic vertebrate model [44]. Seven different types of CNTs were used for exposure at a minimum of three concentrations: SWCNTs, MWCNTs, SWCNHs suspended 
Citation: Jain S, Singh SR, Pillai S (2012) Toxicity Issues Related to Biomedical Applications of Carbon Nanotubes. J Nanomed Nanotechol 3:140. doi:10.4172/2157-7439.1000140

Page 6 of 15

\begin{tabular}{|c|c|c|c|c|}
\hline MATERIAL & METHOD & CONCENTRATON & RESULTS & AUTHOR \\
\hline $\begin{array}{l}\text { Polyamidoamine-MWCNT- } \\
\text { plasmid DNA }\end{array}$ & Hela cells & $50 \mu \mathrm{g} / \mathrm{ml}$ & $\begin{array}{l}\text { Decreased cytotoxicity } \\
\text { by } 38 \%\end{array}$ & [153] \\
\hline MWCNT-COOH;MWCNT-NH ${ }_{2}$ & $\begin{array}{l}\text { Human astrocyte D384 } \\
\text { And lung A549 cells }\end{array}$ & $1 \mu \mathrm{g} / \mathrm{ml}$ & $\begin{array}{l}\text { High solubility and dispersibility, } \\
\text { Reduced toxicity }\end{array}$ & [154] \\
\hline $\begin{array}{l}\text { MWCNT-COOH, } \\
\text { MWCNT- PVA } \\
\text { MWCNT-Apatite } \\
\text { (PVA: Poly Vinyl alcohol) }\end{array}$ & $\begin{array}{l}\text { MG-63 human osteoblastic } \\
\text { cells }\end{array}$ & & $\begin{array}{l}\text { MWCNT-Apatite shows higher cell viability than MWCNT-COOH } \\
\text { and MWCNT-PVA }\end{array}$ & [155] \\
\hline pEGFPplasmid DNA-SWCNT & $\begin{array}{l}\text { Mouse B-cells } \\
\text { cortical neurons }\end{array}$ & $0.1 \mathrm{pM} / 10 \mathrm{~mL}$ & Only $10 \%$ non-viable cells & [156] \\
\hline $\begin{array}{l}\text { Glycopolymer-SWCNT- } \\
\text { plasmid } \\
\text { (pEGFP) }\end{array}$ & HeLa cells & $0.1 \mathrm{mg} / \mathrm{ml}$ & No toxicity & [157] \\
\hline 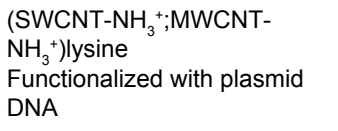 & A549 cells & $150 \mu \mathrm{g} / \mathrm{ml}$ & Good gene delivery vector & [158] \\
\hline $\begin{array}{l}\text { Plasmid DNA-SWCNT and } \\
\text { Plasmid DNA-MWCNT }\end{array}$ & HeLa cell line & $10 \mathrm{mg} / \mathrm{ml}$ & Exhibit low toxicity, improved gene expression up to 10 folds. & [22] \\
\hline $\begin{array}{l}\text { FITC-SWCT and } \\
\text { biotin-SA-SWCNT }\end{array}$ & $\begin{array}{l}\text { HL60,3T3,Chinese hamster } \\
\text { ovary cell }\end{array}$ & $0.05 \mathrm{mg} / \mathrm{ml}$ & $\begin{array}{l}\text { Both the f-CNTs were internalized } \\
\text { inside the cells without toxicity by endocytosis. }\end{array}$ & [63] \\
\hline $\begin{array}{l}\text { f-CNT prepared by } 1,3 \\
\text { cycloaddition and oxidation/ } \\
\text { amidation }\end{array}$ & $\begin{array}{l}\text { B\&T lymphocytes and } \\
\text { macropghages }\end{array}$ & $1-10 \mu \mathrm{g} / \mathrm{ml}$ & $\begin{array}{l}\text { f-CNTs were uptaken by cells, } \\
\text { highly soluble and preserved the } \\
\text { activity of immunoregulatory cells }\end{array}$ & [159] \\
\hline $\begin{array}{l}\text { SWCNT-phenyl- } \mathrm{SO}_{3} \mathrm{H}, \\
\text { SWCNT-phenyl- } \mathrm{SO}_{3} \mathrm{Na} \text {, } \\
\text { SWCNT-phenyl-COOH, } \\
\text { SWCNT in pluronic F108 }\end{array}$ & $\begin{array}{l}\text { Cultured human } \\
\text { Dermal fibroblast }\end{array}$ & $3 \mu \mathrm{g} / \mathrm{ml}-30 \mu \mathrm{g} / \mathrm{ml}$ & $\begin{array}{l}\quad \text { Reduced in toxicity observed with } \\
\text { Increased of degree of functionalization. f-CNT were less toxic } \\
\text { than surfactant stabilized SWCNT. }\end{array}$ & [160] \\
\hline $\begin{array}{l}\text { Pluronic F127(PF127) } \\
\text { surfactant } \\
\text { coated MWCT }\end{array}$ & $\begin{array}{l}\text { Mouse cerebral cortex, } \\
\text { Cultured human } \\
\text { blastoma cells }\end{array}$ & $\begin{array}{c}0.01 \% \\
5-10 \mathrm{~m} \mu \mathrm{g} / \mathrm{ml}\end{array}$ & $\begin{array}{l}\text { No degeneration of neurons, no } \\
\text { Induction of apoptosis, } \\
\text { Presence of MWCNT reduced toxicity of PF127 }\end{array}$ & {$[52,161,162]$} \\
\hline MWCNT- $\mathrm{NH}_{2}$ & Fibroblast L929 cell line & $1-50 \mu \mathrm{g} / \mathrm{ml}$ & Non-toxic but reduced cell growth observed & [163] \\
\hline $\mathrm{NH}_{2}$-MWCNT-DNA & $\begin{array}{l}\text { HUVEC cell \& A375(human } \\
\text { melanoma cell line) }\end{array}$ & $60 \mu \mathrm{g} / \mathrm{ml}$ & No cell toxicity & [164] \\
\hline $\begin{array}{l}\text { SWCNT-AHA } \\
\text { (AHA: 6-aminohexanoic acid) }\end{array}$ & $\begin{array}{l}\text { HEK cells(human } \\
\text { epidermal keratinocytes) }\end{array}$ & $\begin{array}{l}0.00000005- \\
0.05 \mathrm{mg} / \mathrm{ml}\end{array}$ & Maintains cell viability & [165] \\
\hline PEI-MWCNT-DNA & HEpG2 and COS7 cells & $1 \mathrm{mg} / \mathrm{ml}$ & Low toxicity, improved gene expression up to 10 folds. & [166] \\
\hline $\begin{array}{l}\text { Non covalently functionalized } \\
\text { with PEG } \\
\text { (PEG-SWCNT) } \\
\text { Oxidized, covalently } \\
\text { functionalized PEG } \\
\text { (PEG- O- SWCNT) } \\
\text { (PEG: Poly ethylene glycol) }\end{array}$ & mice & $100 \mu \mathrm{l}$ & PEG-SWCNT less toxic than PEG O SWCNT & [167] \\
\hline $\begin{array}{l}\text { MWCNT-COOH, } \\
\text { MWCNT-Amide and } \\
\text { MWCNT- Benezimidazole }\end{array}$ & Fibroblast cells & & Functionalized CNTs show more than $50 \%$ cell viability & [168] \\
\hline
\end{tabular}

Table 1: CNT functionalized with different groups and bio-molecules leading to the reduction of cell toxicity.

in sodium deoxycholate, MWCNTs suspended using sodium deoxycholate, water soluble MWCNTs with sulfonate group (anionic groups), water soluble SWCNTs with PEG (neutral group), covalently functionalized, water soluble SWCNTs with $\mathrm{m}$-polyaminobenzene sulfonic acid (PABS) (zwitterionic group). SWCNTs and MWCNTs that were functionalized to be water soluble were more stimulatory to IL-1 $\beta$ in macrophage cells compared with unfunctionalized counter parts. Almost all the nanomaterials, mentioned above were stimulatory at some concentration. SWCNHs and MWCNT suspensions in sodium deoxycholate were stimulatory from 1 to $10 \mu \mathrm{g} /$ $\mathrm{ml}$ concentration. SWCNTs and MWCNTs that were functionalized to be water-soluble were stimulatory only at highest concentrations (5- 
Citation: Jain S, Singh SR, Pillai S (2012) Toxicity Issues Related to Biomedical Applications of Carbon Nanotubes. J Nanomed Nanotechol 3:140. doi:10.4172/2157-7439.1000140

Page 7 of 15

\section{Functionalized \\ CNT}

Glucosamine-MWCNT

CS-MWCNT

(CS: chitosan)

CS-MWCNT-Cu ${ }^{2+}$

CS-MWCNT

Galactose-MWCNT

PVP-MWCNT

PPy-MWCNT
(PPy: Poly propylene)

a-Pyrene-MWCNT

Pyrene-MWCNT

MWCNT-COOH

MWCNT-Amine

(Amine: dicyandiamide and

phenylbiguamide)

\section{SWCNT-OH}

(hydroxyl nanotubes)

SWCNT-tetrafluoric acetic

group

SWCNT-2-propanol-2-yl

Cellulose-SWCNT

CNT-SDS

(SDS: sodium dodecylsufate;

Anionic surfactant)

CNT-NaDDBS

(NaDDBS: Sodium dodecylbenzene

sulfonate)

Triton-100

SWCNT-pyrene-Protein

SWCNT-PEG-FITC

MWCNT-PEI-DNA

\section{Modification}

approach

Oxidative covalent

Oxidative covalent

Covalent

Wet-grinding assisted ultrasonication

Oxidative covalent

Polymerization and blending

Oxidative covalent

Reversible addition -

fragmentation chain transfer

polymerization

Covalent

Acid oxidation

Oxidative covalent

Fluorine displacement

Covalent

Covalent attachment under UV-light

Covalent

Non-covalent
Biocompatibility/

Solubility

Good biocompatibility
Reduced aggregation, high dispersibility
and long term stability in $2 \%$ acetic acid.
Improved electrical conductivity and stability
Improved wettability and homogeneous dispersion

Improved dispersibility in aqueous solvents.

Remarkable solubility in water ethanol and dimethylformamide (DMF)

Improved solubility and conductivity

Increased solubility with the surface coverage of the polymer.

Improved solubility

Decreased length, increased solubility and colloidal stability in polar solvents like water and ethanol

Uniform dispersion, good interfacial binding, better compatibility

Stable suspension in water, ethanol and dimethyl formamide. Improved compatibility with biomolecules

Improved dispersion in water, ethanol and DMF

Bundle dissociation, improved solubility in organic solvent, retained electronic structure

Easily dispersed and stable for 7 days at the content of $10 \mathrm{mg} / \mathrm{ml}$

Decreased aggregation,

$[182,183]$

Dispersion in both aqueous and organic solvents
Non-covalent
Non-covalent
( $\pi$ - $\pi$ stacking of aromatic FITC)
Non-covalent

[184]

[166]

Table 2: Functionalization strategies for improved solubility and biocompatibility of CNTs.

$10 \mu \mathrm{g} / \mathrm{ml}$ ) similar to positive control LPS. In general, functionalized SWCNTs and MWCNTs were more stimulatory as compared to their unfunctionalized counterparts.

\section{Cytotoxicity}

Treating cells with CNTs can result in a variety of cell fates. There have been reports that CNTs cause necrosis, where cells loose cell 


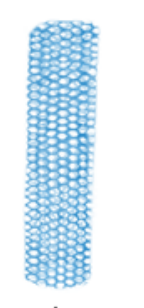

\section{$S P^{2}$ hybridization}

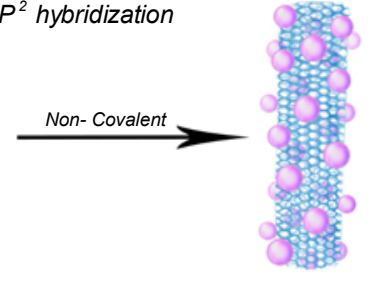

$+$

(3)
$S P^{2}$ hybridization

Less stable

Preserves CNT structure
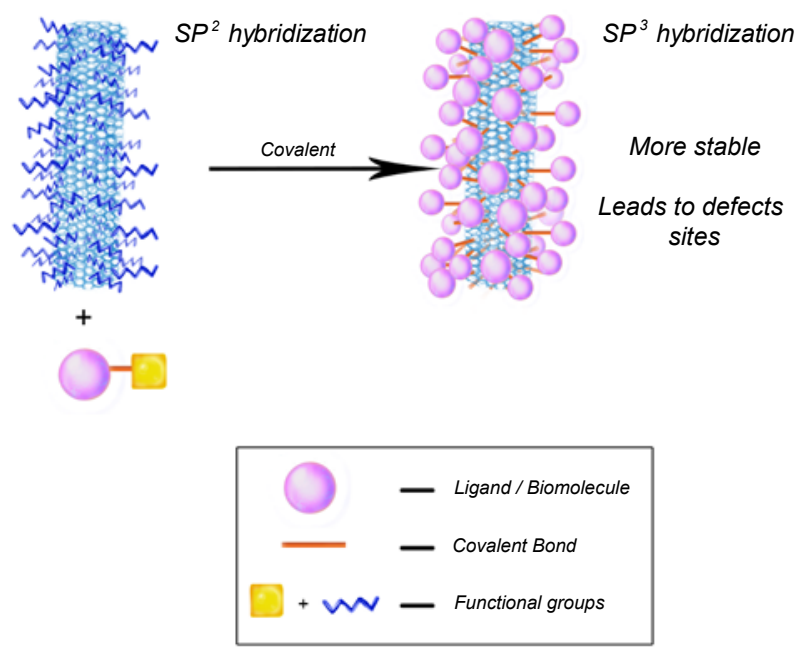

Figure 3: Covalent modification degrades CNT properties by converting $\mathrm{SP}^{2}$ hybridized carbon to $\mathrm{SP}^{3}$ type.

membranes and lyse rapidly [78]. There have been reports that cells stop growing or dividing actively thereby losing their viability on treatment with CNTs. Several authors have reported that cells can activate a genetic program of controlled cell death (apoptosis) [83]. It has been reported that the probable mechanism of photothermal killing of cancer cells with CNTs and grapheme involved necrotic as well as apoptotic cell death characterized by caspase activation/DNA fragmentation and cell membrane damage [103]. Apoptosis-associated genes were up-regulated and tyrosine kinase activities were decreased, with down - regulation of the expression of the related genes [85]. The mechanism of SWCNTs cytotoxicity has been evaluated in terms of induced changes on cytoskeletons and cell morphology. It is known that certain proteins like Focal Adhesion Kinase (FAK) cadherin collagen and fibronectin, play an important role in cell adhesion. CNTs insert into cell membranes and disturb the surface protein receptors. FAK is related to reduced cell proliferation and adhesion. SWCNTs disturb the distribution of FAK in a human cell line (HEK293) along with a decrease in cell adhesion [85]. SWCNTs can indirectly cause toxicity by reacting with culture media and altering their composition and thereby reducing the availability of medium components to the cells. When A549 cells were grown on media, which had previously contained SWCNTs, significant cytotoxicity was observed [104].
Alamar blue assay and clonogenic assay indicated the reduction of proliferative activity of the cells rather than viability.

\section{Dermal toxicity}

Skin is at a high potential for both occupational and environmental exposure to nanoparticles. Additionally, once the nanoparticles are logded inside the avascular epidermis, they escape removal by phagocytosis [105]. Currently, there is a lack of information on whether nanomaterials can actually be absorbed across the skin's stratum corneum and can accumulate in dermal tissues. The products composed of SWCNTs and MWCNTs were tested for their acute dermal toxicity and acute eye irritability using rabbits and skin sensitization using guinea pigs. None of the SWCNTs and MWCNTs caused toxic skin sensitization effects. Only one of the products containing MWCNTs caused slight eye irritation [106]. In other studies, unpurified SWCNTs (containing iron as impurity) tested positive for their dermal toxicity on murine epidermal cells (JB6 P+), EpiDerm FT engineered skin cells and immune competent hairless SKH-1 mice [107]. The large surface area of the skin and small size of nanoparticles makes it difficult to determine their location in the skin and within the systemic circulation. If they are systemically absorbed, CNTs would be diluted throughout the entire body or may be deposited in major organs, thereby making their detection and quantization difficult. Further, CNTs cannot be expected
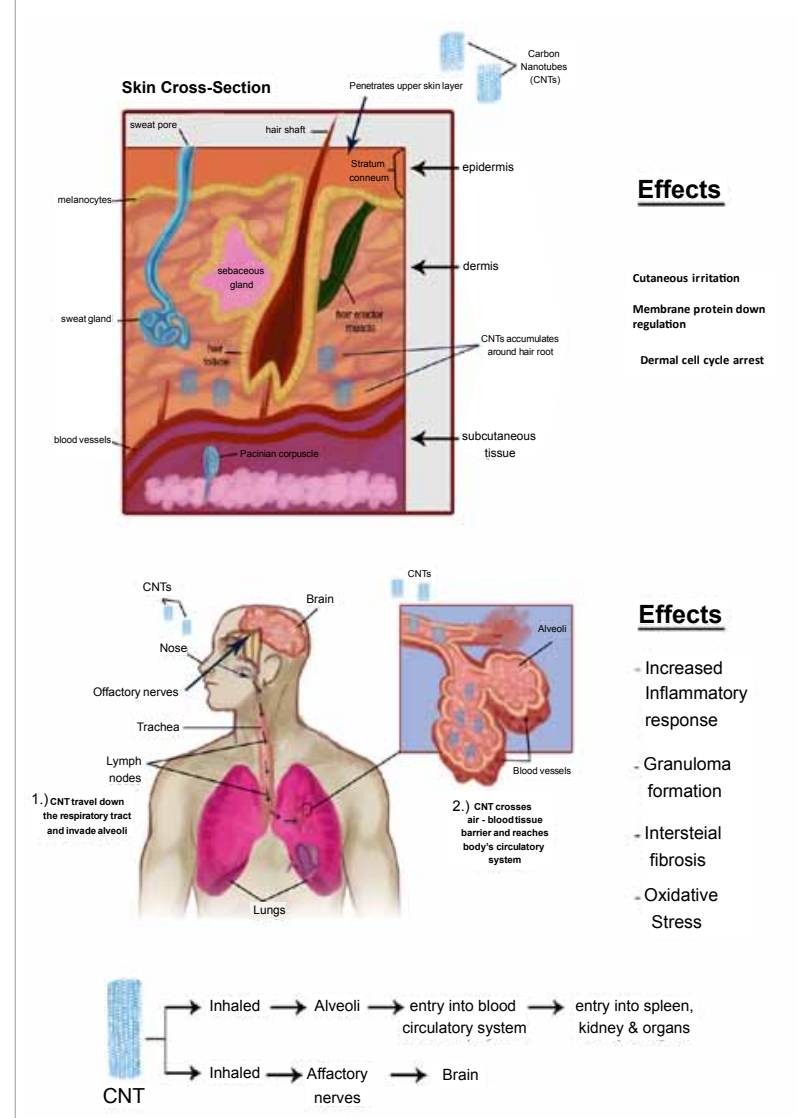

Figure 4: Entry of CNTs inside the human body via (a) indirect uptake by skin pores by crossing the first layer of protection (stratum corneum) and localization around the root of the hair follicles (b) inhalation or respiratory system; where CNTs enters alveoli and deposit on the epithelium from where they cross airblood tissue barrier to enter blood circulatory system and reach other tissues and organs. 
to be absorbed by the skin, similar to chemical absorption as they vary widely in their shape, size and physiochemical properties which could affect their dermotoxic potential and their penetration abilities across the skin. Standardization becomes even more challenging for surface modified CNTs $[75,105,108,109]$. MWCNTs penetrate through the stratum corneum barrier, localize and initiate an irritation response in dermal cells [110]. Proteomics studies were conducted to test the effect of MWCNTs on human epidermal keratinocytes. An increase and decrease in the expression of several proteins was observed in the CNTs treated cells as compared to controls. These altered protein expression patterns on CNT treatment suggest cell cycle inhibition, deregulation of intermediate filament expression, altered vesicular trafficking and membrane protein down-regulation [76]

\section{Pulmonary toxicity}

The release of fine CNTs nanoparticles in the atmosphere is a highly energy intensive process and current dosages and processes do not release significant quantities of airborne CNTs into the atmosphere, but there is a possibile health hazard due to cumulative effects, especially when CNTs are handled in bulk. Nanoparticles may enter a living organism by inhalation, ingestion, cutaneous absorption or through the circulatory system. The respiratory system is one of the most important systems identified for quick absorption and deposition of nanoparticles in the body. Due to their small size, CNTs can easily disperse in air and be inhaled into the lungs. Therefore pulmonary toxicity is of prime importance. Several in vitro $[9,83,111]$ and in vivo $[58,112,113]$ studies have been conducted in the past to assess pulmonary toxicity due to exposure to SWCNTs and MWCNTs. Instillation of SWCNTs into the lungs of rats at a dose of 1 or $5 \mathrm{mg} / \mathrm{kg}$ resulted in granuloma formation [84]. Pulmonary toxicity is evaluated by studying lung index, alkaline phosphate activity measurement (ALP) and oxidative stress pathway evaluation [114]. Type II alveolar cells are responsible for secretion of a hydrolase enzyme, (ALP, alkaline phosphatase) responsible for removal of phosphate groups from different molecules. Thus, increase of ALP activity in serum is an indicator of toxicity to Type II alveolar cells. Lactate Dehydrogenase (LDH) is another measure for toxicity in lungs. It is a cytoplasmic enzyme that catalyses the conversion of lactate to pyruvate in the liver, lung, kidneys etc. The activity of LDH in these tissues is much higher than that in the serum. Increased level of LDH in the serum acts as an indicator of alveolar macrophage injury, which leads to necrosis in the tissues.

Oxidative stress is yet another reliable measure for evaluation of the toxic response in general. When nanoparticles enter into the lungs, oxidative stress leads to increased production of ROS, which then trigger lipid oxidation, and formation of Malondialdehyde (MDA), and also Glutathione (GSH) an antioxidant that helps protect cells and tissues from ROS. When lung damage occurs, there is an increase in MDA level and decrease in GSH level $[115,116]$.

There are several factors that control the distribution of nanomaterials within different parts of the respiratory tract, such as their chemical reactivity with body proteins, the size or surface characteristics [40]. Unlike fine particles, CNTs can escape clearance by macrophages and travel from the alveoli to the blood circulation followed by possible migration to other organs of the body. Physical characteristics of nanoparticles like size, surface modifications etc. play a crucial role in extra-pulmonary translocation of nanoparticles [107]. Once the nanoparticles are deposited, they are translocated to extrapulmonary sites, from where they reach the circulatory system via transcytosis (Figure 4). Removal of these deposited particles may take place via physical as well as chemical translocation processes [112]. The soluble components of nanoparticles either in lipids or in intracellular fluid undergo absorption into protein or subcellular components, or into extracellular fluids [117]. Several studies on biodistribution of nanoparticles reveal that significant amounts of carbon-based particles $\left(80-180 \mu \mathrm{g} / \mathrm{m}^{3}\right)$ were found in the liver of rats on inhalation exposure [118]. In another study, inhaled carbon particles reached the central nervous system [119]. Alveolar macrophages are the first line of defense against invading nanoparticles in the lung. Instillation of $0.5 \mathrm{mg}$ SWCNTs into mice induced macrophage activation and subsequent pulmonary injury [120]. A dose dependent increase in inflammatory response was observed on treatment of mice with SWCNTs. The aggregated CNTs were responsible for granulomaous inflammation, including discrete granulomas with hypertrophic epithelial cells in the lungs after 60 days of exposure [121].

Most of the inhaled nanoparticles are eliminated from the body system by macrophages, through phagocytosis. The particles that are not removed by phagocytosis, enter epithelial cells or find their way into interstitial spaces. They may finally enter the systemic circulation and the lymphatic system [40]. CNTs have been observed in liver tissues of rats following inhalation [122]. Studies utilizing intratracheal instillation of nanoparticles revealed the agglomerative nature of CNTs in aqueous solutions [123-125]. Similar to this, pharyngeal aspiration have shown evidence of agglomeration of CNTs in the proximal alveolar regions of lungs.

\section{Genotoxicity}

Genotoxicity can be described as the deleterious effect of nanoparticles on a cell's genetic material. CNTs have the affinity to interact with DNA, thus rendering them potentially mutagenic or carcinogenic. Owing to their cohesive nature, CNTs tend to form stable aggregates inside organisms, causing inflammatory as well as oxidative stress at the sites of their deposition. These effects, over the course of time might lead to tissue/organ destruction and increase the risk

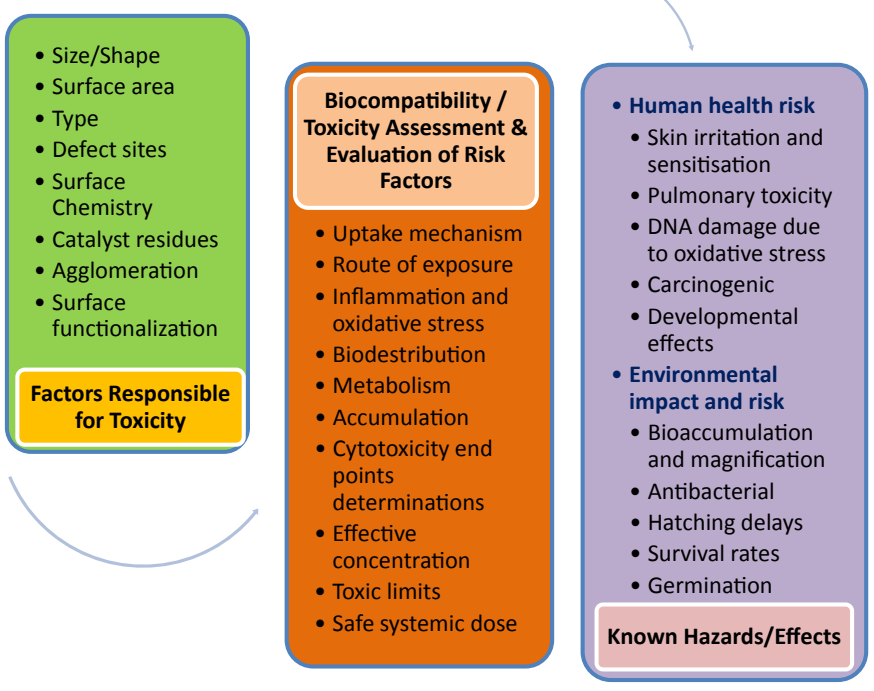

Figure 5: Concept map explaining the various toxicity issues surrounding CNTs and the risk assessment of accidental exposure on human health and environment. 
of cancer. Since the first alarm raised by the Royal Society and Royal Academy of Engineering in 2004, an enormous amount of research has been conducted on genotoxicity issues of nanomaterials [126-131].

CNTs are able to induce cancer and mesothelioma in a similar manner as asbestos. Within biological systems, they remain stable and form aggregates in the micrometer size range. Animal studies have indicated that MWCNTs and SWCNTs can induce stress related inflammatory responses, reactive oxygen and nitrogen species and genotoxic effects associated with these effects [132]. Carcinogenic properties of CNTs are associated with long term genotoxic stress. There are two ways CNTs can interact to cause genotoxicity, one is direct interaction with DNA or the mitotic apparatus or indirectly via oxidative stress and the inflammatory response. Eukaryotic cells develop several repair mechanisms in response to DNA damage, to protect genomic integrity [133]. For instance, in the presence of damaged DNA, the $\mathrm{p} 53$ protein is activated by protein phosphorylation as a master guardian that arrests the cell cycle to provide time to repair DNA damage. If the DNA damage goes beyond repair, enhanced expression of p53 may trigger cell death by apoptosis. Under normal conditions, when DNA is not damaged, p53 is expressed at lower levels. Since the activation of 553 could be related to DNA damage, it could be used as a molecular marker for assessing genotoxicity of MWCNTs to mouse embryonic stem cells.

MWCNTs have long and thin morphology and produce asbestos like toxic responses. There have been interesting studies conducted on intra-abdominal injection of MWCNTs with mesothelioma inducing effects [134]. The toxic effects of metal particles such as $\mathrm{CuO}, \mathrm{TiO}_{2}$, $\mathrm{CuZn} \mathrm{Fe}_{2} \mathrm{O}_{4}, \mathrm{Fe}_{3} \mathrm{O}_{4}, \mathrm{Fe}_{2} \mathrm{O}_{3}$, were compared with those of SWCNTs and MWCNTs using human lung epithelium cell lines. The highest toxic effects were observed for copper nanoparticles and lowest for iron particles $\left(\mathrm{Fe}_{3} \mathrm{O}_{4}, \mathrm{Fe}_{2} \mathrm{O}_{3}\right)$ [110]. CNTs were cytotoxic and also caused DNA damage [135].

In order to identify the affected genes by SWCNTs in Human Normal Lung Cells (HNBE), gene expression profiles of untreated and SWCNTs treated HNBE cells have been studied [45]. The microarray analysis leads to the identification of marked changes in the gene expression of 14,294 genes, with 7,029 genes being upregulated and 7,265 being downregulated. SWCNTs treatment results in cell apoptosis of HNBE cells through the activation of transcription factors $2,3,7$ and 15 . The gene responsible for cell survival, growth arrest, and DNA damage, protein phosphatase 1 was overexpressed on SWCNTs treatment in HNBE cells. Transcription factor 3 gene, responsible for cell apoptosis and carcinogenesis was overexpressed in HNBE cells treated with SWCNTs. The interleukin receptor 1 gene, responsible for cell signaling of airway inflammation through its activation by interleukin 33, was overexpressed in HNBE cells treated with SWCNTs. Downregulation of the hyaluronan-mediated motility receptor gene, which is involved in cell motility and cell growth was observed in HNBE cells with SWCNTs treatment. The identification and profiling of the gene expression in HNBE cells on SWCNTs treatment adds to our understanding of the mechanism of the effect of SWCNTs on human health. A preliminary protein profile of MWCNTs exposure to Human Epidermal Keratinoctes (HEKs) shows that MWCNTs are capable of altering the protein expression in a target epithelial cell [76]. Proteins associated with metabolism, cell signaling, stress and cytoskeletal elements and vesicular trafficking are significantly affected. Another study aimed to assess the toxicity exhibited by MWCNTs and to explore possible molecular mechanisms underlying the biological effects of MWCNTs exposure in A549 cells was conducted [43]. Results clearly indicated that $200 \mu \mathrm{g} / \mathrm{ml}$ concentration of MWCNTs decreased cell viability considerably in A549 cells. MWCNTs stimulated the generation of ROS which released the pro-inflammatory cytokines and caused the translocation of transcription factor NF-kB, to the nucleus, which regulates pro-inflammatory gene for IL-8. Proteomics study was conducted to evaluate the effects of MWCNTs on protein expression profile in human monoblastic leukemia cells (U937) [136]. Difference in protein expression pattern was observed on treatment with MWCNTs with different impurities within the CNTs by thermally treating highly contaminated As-grown MWCNTs at $1800^{\circ} \mathrm{C}$ (HTT1800) and $2800^{\circ} \mathrm{C}$ (HTT2800). Alteration of protein expression of 45 proteins, that play key roles in metabolism, biosynthesis, stress related response and cell differentiation was observed after treatment with HTT1800 and HTT2800 tubes. HTT2800 did not inhibit cell proliferation and were found to be non-toxic to U937 cells. The biomarker protein of Parkinson's disease, DJ-1, also related to cancer, was identified after exposure to both MWCNTs. The results concluded that cytotoxicty of MWCNTs depends on impurities such as iron, although MWCNTs themselves cause cytotoxic responses in vitro [136].

\section{Risks from accidental exposure, regulatory concerns and commercial market potential of CNTs}

The wide variety of applications of CNTs has revolutionized the field of electronics, energy storage, material science and engineering, diagnostics and biomedicine. However, challenges for safe use of CNTs because of their potential toxicity have slowed down the efforts for further innovation in their applications, especially in the biomedical field. As the large scale production and utilization of nanomaterials increase, so does the risk to human health and environment. The toxic effects of CNTs and other nanomaterials are not fully characterized, and as the field grows, the need for standardization and categorization will increase so that results can be compared and analyzed for potential risks [137]. As per the US Environmental Protection Agency (EPA), CNTs are regarded as a "chemical substance" under the toxic substances control act (TSCA). EPA permits only limited manufacturing, use and environmental release of CNTs as they could create a serious threat to environmental safety [138]. According to recent (June, 2011) EPA reports, MWCNTs have been designated as a chemical substance hazardous to human health.

There is a complex array of issues surrounding toxicity of CNTs including the route of entry, chemical modification and others (Figure 5). The most common routes of entry of CNTs inside the human body are inhalation, dermal exposure or ingestion. Dermal exposure could lead to skin irritation, sensitization, skin cancer or produce systemic effects after absorption. Functionalized CNTs with hydrophilic functionalities prevent their aggregation and allows their circulation in the respiratory system for longer duration after inhalation. Several questions are relevant to the health risk assessment of CNTs such as how quickly the inhaled nanotubes are cleared from the lungs, the fate of the persisting nanotubes and how shape, size, surface charge, metal impurities, surface functionalization and the degree to which they agglomerate influence toxicity of CNTs. CNTs functionalized simultaneously with various molecules of particular interest display unique properties that may impact human health and thus require reliable characterization, standardization and evaluation of their in vitro toxicity behavior in representative cell lines. The chronic exposure to these engineered CNTs could make the situation more complicated as their toxicity data base management and documentation is difficult. The in vitro and in vivo impact of CNTs may vary depending on surface functionalization. They have been shown to cross the blood-brain- 
barrier which could lead to adverse health and associated risks [139]. Much has been written speculatively on the potential health risks of carbon nanotubes, mostly as an afterthought to variety of application prospects. Recently, the dose-response and time course of pulmonary toxicity of Baytubes, a more flexible MWCNTs type has been examined in previous single and repeated exposure 13 week rat inhalation studies [140]. Also, kinetic endpoints and potential to translocate to extra pulmonary organs studies provide better understanding of dosimetric response and etiopathology of pulmonary inflammation. Baytubes show remarkable similarity in retention half-time $\left(\mathrm{t}_{1 / 2}\right)$ with poorly soluble and agglomerated carbon black (carbon black at $7 \mathrm{mg} / \mathrm{m}^{3}$ has $\mathrm{t}_{1 / 2}=329$ days; MWCNTs at $6 \mathrm{mg} / \mathrm{m}^{3}$ has $\mathrm{t}_{1 / 2}=375$ days). The study supports the conclusion that the difference in the pulmonary toxic potency is related to the low density $\left(\approx 0.1-0.3 \mathrm{~g} / \mathrm{m}^{3}\right)$ of MWCNTs assemblage [21]. Hence, the nanoparticles, attain the volumetric lung overload-related inflammatory response conditions earlier than the conventional particles. The pulmonary overload triggers the cascade of events to slow down the clearance and consequently increase MWCNTs concentration that leads to sustained pulmonary inflammation. Based on NOAEL (No-Observed Adverse Effect Level) from the 13 week inhalation study on rats, an occupational exposure limit (OEL) of 0.05 $\mathrm{mg}$ Baytubes $/ \mathrm{m}^{3}$ (time weighed average) is considered reasonably safe and does not cause lung injury on accidental inhalation. A promising new method for detailed safety evaluation using proteomics-based approach has also been used for assessment of biological responses to nanomaterials [136]. If the protein database related to all diseases is established, protein matching will be an efficient method for evaluation of the possibility of whether MWCNTs cause disease. Thus, proteomics based approach allows safety evaluation of CNTs and other nanomaterials and also provides information about secondary influence, impurities and response mechanism.

There are other issues that may come in the way of evaluation of CNTs toxicity and the formulation of reasonable regulatory guidelines, such as the correct determination of cytoxicity endpoints. Carbon based materials interact with the dye markers used in cell-culture cytotoxicity assays such as Neutral Red, NR (3-amino-7dimethylamino-2 methylphenazine hydrochloride) and MTT (3-[4, 5-Dimethyl-2-thiazol]-2, 5-phenyl-2H-tetrazolium bromide) that are widely utilized for cell viability assays. The adsorption of these dyes from the cell culture media interferes with the absorption spectra causing false readings and incorrect evaluation of the toxicity of CNTs [105]. Thus accurate identification of CNTs toxicity requires a matrix based on a set of representative cell lines and in vitro cytotoxicity assays measuring different cytotoxicity endpoints.

Despite toxicity, safety and regulatory concerns, CNTs have received considerable attention from scientists because of their immense potential for commercialization in a variety of applications. The visionaries and the futurists are thrilled by the properties of CNTs as in theory they could be used to build incredibly strong structures such as, 'space elevators' that would stretch thousands of miles from earth. Nanocomp' technologies Inc. are trying to bring the future closer by commercially producing yarns and sheets made of CNTs [141]. Bayer Materials Science synthesized a multifilament yarn coated with CNTs to make new fabric heater with improved electrical and thermal conductivity that shows long lasting bending resistance [142]. Bayer used epoxy gel coat modified with Baytubes, the CNTs from Bayer for reinforcing the outer surface of a kayak. The coating makes the surface resistant to abrasion and easy to clean [143]. Nanoledge manufactures tennis rackets with the material reinforced with CNTs. The racket bends less during ball impact and improves the performance of the player [144]. Recently Ensysce Bioscience developed SWCNTs conjugated siRNA for treatment of cancer. They received regulatory approval to conduct clinical trials on siRNA delivery into tumor cells $[11,145,146]$. Recently FDA has approved the use of CNTs to improve colorectal cancer imaging. The research is focused on clinical trials on ovarian and non-small cell lung cancer diagnostics using CNTs. Even though CNTs play a lead role in the field of nanomedicine to get clinical approval as a drug delivery vehicle, more research is required to guarantee safety. In a breakthrough discovery by a team of Swedish and American scientists, CNTs have been shown to break down to carbon dioxide and water by an enzyme-meyloperoxidase found in white blood cells [147]. This contradicts the previous assumptions that CNTs were non-biodegradable and cannot be broken down in the body or in nature. This discovery will probably change the face of nanomedicine with increased use of CNTs for diagnosis and treatment.

\section{Conclusions}

Although the potential of CNTs as a useful nanomaterial for biomedical applications cannot be denied, the failure to reach a consensus on their toxicity hampers the future prospects for clinical trials as safe drug delivery vehicles. Functionalization of CNTs allows for improved solubility and biocompatibility and opens new avenues for their utilization in the field of nanomedicine. Only through a relative comparison can one understand the dangers of functionalized CNTs administration against other treatment options available. The toxicity of CNTs is likely to be influenced by the method used to manipulate their surfaces. Characterization, uptake by cells and elimination mechanisms need to be understood properly and new test systems are needed in order to systematically study the nanotoxic behavior of CNTs and reveal important features necessary for risk assessment. It is recommended that the issues regarding toxicity of CNTs be ameliorated by functionalization before biomedical application. With increasing production of CNTs, there is an urgent need to refine strategies to assess their possible effects on employees, who represent the main exposed population so that appropriate safety regulation can be formulated. Standardized protocols to evaluate the toxicity of CNTs and categorize their associated risks would help to accelerate their routine application. Current toxicity reports on biological risk may have to be evaluated in the context of exposure due to ambient environment. Additionally, the hazards of treatment with CNTs need to be compared with other treatments to arrive at safe doses and relative benefits of CNTs over current regimens. If the risk/benefit aspects are satisfactorily answered, then the use of CNTs in biological systems might be feasible. Continued efforts of researchers and scientists, on CNTs may result in safer products to enhance the quality of human health and environment.

\section{Acknowledgement}

This work was supported by NSF-CREST (HRD-07342321). We would like to thank Ms. Eva Dennis for creating some of the figures used in the manuscript.

\section{References}

1. Goldman L, Coussens C (2005) Implications of Nanotechnology for Environmental Health Research. Roundtable on Environmental Health Sciences Research and Medicine National Academies Press (US).

2. lijima S (1991) Helical microtubules of graphitic carbon. Nature 354: 56-58.

3. Subramanian K, Wong YM, Kang WP, Davidson JL, Choi BK, et al. (2007) Field emission devices for advanced electronics comprised of lateral nanodiamond or carbon nanotube emitters. Diam Relat Mater 16: 1997-2002.

4. Tsukagoshi K, Yoneya N, Uryu S, Aoyagi Y, Kanda A, et al. (2002) Carbon nanotube devices for nanoelectronics. Physica B Condens Matter 323: 107 114 
Citation: Jain S, Singh SR, Pillai S (2012) Toxicity Issues Related to Biomedical Applications of Carbon Nanotubes. J Nanomed Nanotechol 3:140. doi:10.4172/2157-7439.1000140

5. Shurpo NA, Serov SV, Shmidt AV, Margaryan HL, Kamanina NV, et al. (2009) Features of fullerenes and carbon nanotubes for nonlinear optics and display application. Diam Relat Mater 18: 931-934.

6. Cui Y, Liu C, Hu S, Yu X (2011) The experimental exploration of carbon nanofiber and carbon nanotube additives on thermal behavior of phase change materials. Solar Energy Materials and Solar Cells 95: 1208-1212.

7. Hwang HJ, Jung SL, Cho KH, Kim YJ, Jang H, et al. (2010) Tribological performance of brake friction materials containing carbon nanotubes. Wear 268: $519-525$.

8. Morsy MS, Alsayed SH, Aqel M (2011) Hybrid effect of carbon nanotube and nano-clay on physico-mechanical properties of cement mortar. Construction and Building Materials 25: 145-149.

9. Zhao X, Liu R (2012) Recent progress and perspectives on the toxicity of carbon nanotubes at organism, organ, cell, and biomacromolecule levels. Environment International 40: 244-255.

10. Tasis D, Tagmatarchic N, Bianco A, Prato M (2006) Chemistry of carbon nanotubes. Chem Rev 106: 1105-1136.

11. Beg S, Rizwan M, Sheikh AM, Hasnain MS, Anwer K, et al. (2011) Advancement in carbon nanotubes: basics, biomedical applications and toxicity. J Pharm Pharmacol 63: 141-163.

12. Bianco A, Kostarelos K, Partidos CD, Prato M (2005) Biomedical applications of functionalised carbon nanotubes. Chem Commun (Camb) 5: 571-577.

13. Liu Z, Chen K, Davis C, Sherlock S, Cao Q, et al. (2008) Drug delivery with carbon nanotubes for in vivo cancer treatment. Cancer Res 68: 6652-6660.

14. Naga AP, Siddqui A (2011) Nanomedical Platform for Drug Delivery. J Nanomedic Nanotechnol 2: 122

15. Truong NK (2011) Targeted Nanoparticles for Cancer Therapy: Promises and Challenges. J Nanomedic Nanotechnol 2: 103

16. Benincasa M, Pacor S, Wu W, Prato M, Bianco A, et al. (2010) Antifungal Activity of Amphotericin B Conjugated to Carbon Nanotubes. ACS Nano 5: 199-208

17. Wu W, Wieckowski S, Pastorin G, Benincasa M, Klumpp C, et al. (2005) Targeted Delivery of Amphotericin B to Cells by Using Functionalized Carbon Nanotubes. Angew Chem Int Ed Engl 44: 6358-6362.

18. Prato M, Kostarelos K, Bianco A (2007) Functionalized carbon nanotubes in drug design and discovery. Acc Chem Res 41: 60-68.

19. Annamalai SK, Palani B, Chandrasekara Pillai K (2012) Highly stable and redox active nano copper species stabilized functionalized-multiwalled carbon nanotube/chitosan modified electrode for efficient hydrogen peroxide detection. Colloids Surf A Physicochem Eng Asp 395: 207-216.

20. Liu YL, Chen WH, Chang YH (2009) Preparation and properties of chitosan/ carbon nanotube nanocomposites using poly(styrene sulfonic acid)-modified CNTs. Carbohydr Polym 76: 232-238.

21. ILS (2000) The relevance of the rat lung response to particle overload for human risk assessment: A workshop consensus report. ILSI Risk Science Institute Workshop Participants. Inhal Toxicol 12: 1-17.

22. Pantarotto D, Singh R, McCarthy D, Erhardt M, Briand JP, et al. (2004) Functionalized carbon nanotubes for plasmid DNA gene delivery. Angew Chem Int Ed Engl 43: 5242-5246.

23. Zhang Z, Yang X, Zhang Y, Zeng B, Wang S, et al. (2006) Delivery of telomerase reverse transcriptase small interfering RNA in complex with positively charged single-walled carbon nanotubes suppresses tumor growth. Clin Cancer Res 12: 4933.

24. Varkouhi AK, Foillard S, Lammers T, Schiffelers RM, Doris E, et al. (2011) SiRNA delivery with functionalized carbon nanotubes. Int J Pharm 416: 419425

25. Chen $\mathrm{H}$, Ma X, Li Z, Shi Q, Zheng W, et al. (2012) Functionalization of singlewalled carbon nanotubes enables efficient intracellular delivery of siRNA targeting MDM2 to inhibit breast cancer cells growth. Biomed Pharmacother.

26. Wang J, Liu G, Jan MR (2004) Ultrasensitive electrical biosensing of proteins and DNA: Carbon-nanotube derived amplification of the recognition and transduction events. J Am Chem Soc 126: 3010-3011.

27. http://plausible.custompublish.com/cparticle54173-5911html
28. Bsoul A, Mohammed AMS, Takahata K (2011) Piezoresistive pressure sensor using vertically aligned carbon-nanotube forests. Electronics Letters 47: 807808.

29. Stampfer C, Helbling T, Obergfell D, Schöberle B, Tripp MK, et al. (2006) Fabrication of Single-Walled Carbon-Nanotube-Based Pressure Sensors. Nano Letters 6: 233-237.

30. Weber JE, Pillai S, Ram MK, Kumar A, Singh SR (2011) Electrochemical impedance-based DNA sensor using a modified single walled carbon nanotube electrode. Mater Sci Eng C 31: 821-825.

31. Janat-Amsbury MM, Yockman JW, Lee M, Kern S, Furgeson DY, et al. (2004) Combination of local, nonviral IL12 gene therapy and systemic paclitaxel treatment in a metastatic breast cancer model. Mol Ther 9: 829-836.

32. Yu X, Munge B, Patel V, Jensen G, Bhirde A, et al. (2006) Carbon nanotube amplification strategies for highly sensitive immunodetection of cancer biomarkers. J Am Chem Soc 128: 11199-11205

33. Webster TJ, Tran P (2011) Nanotechnologies For Cancer Diagnostics and Treatment. Nanotechnology: Nanofabrication, Patterning and Self Assembly 107-150.

34. Beer C, Foldbjerg R, Hayashi Y, Sutherland DS, Autrup H, et al. (2012) Toxicity of silver nanoparticles-Nanoparticle or silver ion? Toxicol Lett 208: 286-292.

35. Pham CH, Yi J, Gu MB (2012) Biomarker gene response in male Medaka (Oryzias latipes) chronically exposed to silver nanoparticle. Ecotoxicol Environ Saf 78: 239-245.

36. Zhu X, Chang Y, Chen $Y$ (2010) Toxicity and bioaccumulation of $\mathrm{TiO}_{2}$ nanoparticle aggregates in Daphnia magna. Chemosphere 78: 209-215.

37. Yoksan R, Chirachanchai S (2008) Amphiphilic chitosan nanosphere: Studies on formation, toxicity, and guest molecule incorporation. Bioorg Med Chem 16 2687-2696.

38. Xingchen Zhao RL (2012) Recent progress and perspectives on the toxicity of carbon nanotubes at organism, organ, cell, and biomacromolecule levels. Environ Int 40: 244-256.

39. Firme CP, Bandaru PR (2010) Toxicity issues in the application of carbon nanotubes to biological systems. Nanomedicine 6: 245-256.

40. Oberdörster G, Oberdörster E, Oberdörster J (2005) Nanotoxicology: an emerging discipline evolving from studies of ultrafine particles. Environ Health Perspect 113: 823-839.

41. Weng MF, Chang BJ, Chiang SY, Wang NS, Niu H (2012) Cellular uptake and phototoxicity of surface-modified fluorescent nanodiamonds. Diamond and Related Materials 22: 96-104.

42. Bystrzejewska-Piotrowska G, Golimowski J, Urban PL (2009) Nanoparticles: Their potential toxicity, waste and environmental management. Waste Management 29: 2587-2595.

43. Ye SF, Wu YH, Hou ZQ, Zhang QQ (2009) ROS and NF-kB are involved in upregulation of IL-8 in A549 cells exposed to multi-walled carbon nanotubes. Biochem Biophys Res Commun 379: 643-648.

44. Klaper R, Arndt D, Setyowati K, Chen J, Goetz F (2010) Functionalization impacts the effects of carbon nanotubes on the immune system of rainbow trout, Oncorhynchus mykiss. Aquat Toxicol 100: 211-217.

45. Alazzam A, Mfoumou E, Stiharu I, Kassab A, Darnel A, et al. (2010) Identification of deregulated genes by single wall carbon-nanotubes in human normal bronchial epithelial cells. Nanomedicine nanotechnology biology and medicine 6: 563-569.

46. Pulskamp K, Wörle-Knirsch JM, Hennrich F, Kern K, Krug HF (2007) Human lung epithelial cells show biphasic oxidative burst after single-walled carbon nanotube contact. Carbon 45: 2241-2249.

47. Liu J, Legros S, Ma G, Veinot JGC, von der Kammer F, et al. (2012) Influence of surface functionalization and particle size on the aggregation kinetics of engineered nanoparticles. Chemosphere 87: 918-924.

48. Prathna TC, Chandrasekaran N, Mukherjee A (2011) Studies on aggregation behaviour of silver nanoparticles in aqueous matrices: Effect of surface functionalization and matrix composition. Colloids Surf A: Physicochem Eng Asp 390: 216-224.

49. Pulskamp K, Diabaté S, Krug HF (2007) Carbon nanotubes show no sign of acute toxicity but induce intracellular reactive oxygen species in dependence 
Citation: Jain S, Singh SR, Pillai S (2012) Toxicity Issues Related to Biomedical Applications of Carbon Nanotubes. J Nanomed Nanotechol 3:140. doi:10.4172/2157-7439.1000140

Page 13 of 15

on contaminants. Toxicology Letters 168: 58-74.

50. Bottini M, Bruckner S, Nika K, Bottini N, Bellucci S,et al. (2006) Multi-walled carbon nanotubes induce T lymphocyte apoptosis. Toxicol Lett. 160: 121-126.

51. Magrez A, Kasas S, Salicio V, Pasquier N, Seo JW, et al. (2006) Cellular toxicity of carbon-based nanomaterials. Nano Letters 6: 1121-1125.

52. Vittorio O, Raffa V, Cuschieri A (2009) Influence of purity and surface oxidation on cytotoxicity of multiwalled carbon nanotubes with human neuroblastoma cells. Nanomedicine 5: 424-431.

53. Donaldson K, Stone V, Tran CL, Kreyling W, Borm PJA, et al. (2004) Nanotoxicology. Occup Environ Med 61: 727-728.

54. Poland CA, Duffin R, Kinloch I, Maynand A, William AHW et al. (2008) Carbon nanotubes introduced into the abdominal cavity of mice show asbestos-like pathogenicity in a pilot study. Nat Nanotechnol 3: 423-428.

55. Tian F, Cui D, Schwarz H, Estrada GG, Kobayashi H, et al. (2006) Cytotoxicity of single-wall carbon nanotubes on human fibroblasts. Toxicology In Vitro 20 : 1202-1212.

56. Tran PA, Zhang L, Webster TJ (2009) Carbon nanofibers and carbon nanotubes in regenerative medicine. Adv Drug Deliv Rev 61: 1097-1114.

57. Jiang J, Oberdörster G, Biswas $P$ (2009) Characterization of size, surface charge, and agglomeration state of nanoparticle dispersions for toxicological studies. J Nanopart Res 11: 77-89.

58. Aillon KL, Xie Y, El-Gendy N, Berkland CJ, Forrest ML, et al. (2009) Effects of nanomaterial physicochemical properties on in vivo toxicity. Adv Drug Deliv Rev 61: 457-466

59. Pantarotto D, Partidos CD, Graff R, Hoebeke J, Briand JP, et al. (2003) Synthesis, Structural Characterization, and Immunological Properties of Carbon Nanotubes Functionalized with Peptides. J Am Chem Soc 125: 61606164.

60. Kam NWS, Jessop TC, Wender PA, Dai H (2004) Nanotube Molecular Transporters: Internalization of Carbon Nanotube Protein Conjugates into Mammalian Cells. J Am Chem Soc 126: 6850-6851.

61. Yu Y, Zhang Q, Mu Q, Zhang B, Yan B, et al. (2008) Exploring the Immunotoxicity of Carbon Nanotubes. Nanoscale Research Letters 3: 271-277.

62. Kam NWS, Dai H (2005) Carbon Nanotubes as Intracellular Protein Transporters: Generality and Biological Functionality. J Am Chem Soc 127 : 6021-6026.

63. Kam NWS, Jessop TC, Wender PA, Dai H (2004) Nanotube molecular transporters: Internalization of carbon nanotube-protein conjugates into mammalian cells. J Am Chem Soc 126: 6850-6851.

64. Herweijer MA, Berden JA, Kemp A, Slater EC (1985) Inhibition of energy -transducing reactions by 8-nitreno-ATP covalently bound to bovine heart submitchondrial particles:direct interaction between ATPase and redox enzymes. Biochem Biophys Acta 809: 81-89.

65. Kam NWS, Wisdom JA, Dai H (2005) Carbon nanotubes as multifunctional biological transporters and near-infrared agents for selective cancer cell destruction. Proc Natl Acad Sci USA 102: 11600-11605.

66. Smythe E (2003) Clathrin-coated vesicle formation:a paradigm for coatedvesicle formation. Biochem Soc Trans 31: 736-739.

67. Rappoport JZ, Simon SM (2009) Endocytic trafficking of activated EGFR is AP-2 dependent and occurs through preformed clathrin spots. J Cell Sci 122: 1301-1305.

68. Bianco A, Kostarelos K, Prato M (2005) Applications of carbon nanotubes in drug delivery. Curr Opin Chem Biol 9: 674-679.

69. Yang W, Thordarson P, Gooding JJ, Ringer PS, Baret F, et al. (2007) Carbon Nanotubes for Biological and Biomedical Applications. Nanotechnology 18: $1-12$.

70. Kostarelos K, Lacerda L, Pastorin G, Wu W, Wieckowski S, et al. (2007) Cellular uptake of functionalized carbon nanotubes is independent of functional group and cell type. Nat Nanotechnol 2: 108-113.

71. Pantarotto D, Briand JP, Prato, M, Bianco A (2004) Translocation of bioactive peptides across cell membranes by carbon nanotubes. Chem Commun 1: 1617.
72. Cheung W, Pontoriero F, Taratula O, Chen AM, He H (2010) DNA and carbon nanotubes as medicine. Adv Drug Deliv Rev 62: 633-649.

73. Klumpp C, Kostarelos K, Prato M, Bianco A (2006) Functionalized carbon nanotubes as emerging nanovectors for the delivery of therapeutics. Biochimica et Biophysica Acta (BBA) - Biomembranes 1758: 404-412.

74. Orynbayeva Z, Singhal R, Vitol EA, Schrlau MG, Papazoglou E, et al. (2011) Physiological validation of cell health upon probing with carbon nanotube endoscope and its benefit for single-cell interrogation. Nanomedicine.

75. Lopez CF, Nielsen SO, Moore PB, Klein ML (2011) Understanding nature's design for a nanosyringe. Proc Natl Acad Sci USA 101: 4431-4434.

76. Witzmann FA, Monteiro-Riviere NA (2004) Multi-walled carbon nanotube exposure alters protein expression in human keratinocytes. Nanomedicine 2 158-168.

77. Xiao GG, Wang M, Li N, Loo JA, Nel AE, et al. (2003) Use of proteomics to demonstrate a hierarchical oxidative stress response to diesel exhaust particle chemicals in a macrophage cell line. J Biol Chem 278: 50781-50790.

78. Wang J, Sun P, Bao Y, Liu J, An L, et al. (2011) Cytotoxicity of single-walled carbon nanotubes on PC12 cells. Toxicology In Vitro 25: 242-250.

79. Valko M, Leibfritz D, Moncol J, Cronin MTD, Mazur M, et al. (2007) Free radicals and antioxidants in normal physiological functions and human disease. Int J Biochem Cell 39: 44-84.

80. Azad N, lyar A, Wang L, Liu Y, Lu Y, et al. (2012) Reactive oxygen speciesmediated p38 MAPK regulates carbon nanotube-induced fibrogenic and angiogenic responses. Nanotoxicology.

81. Coleman JN, Khan U, Blau WJ, Gun'ko YK (2006) Small but strong: A review of the mechanical properties of carbon nanotube-polymer composites. Carbon 44: 1624-1652.

82. Guo YY, Zhang J, Zheng YF, Yang J, Zhu X, et al. (2011) Cytotoxic and genotoxic effects of multi-wall carbon nanotubes on human umbilical vein endothelial cells in vitro. Mutat Res 721: 184-191.

83. Giorgio D, Laura MB,Sebastino DR, Aimola AM, Santucci P, et al. ( 2011) Effects of single and multi walled carbon nanotubes on macrophages: Cyto and genotoxicity and electron microscopy. Mutat Res 722: 20-31.

84. Warheit DB, Laurence BR, Reed KL, Roach DH, Reynolds GA, et al. (2004) Comparative pulmonary toxicity assessment of single-wall carbon nanotubes in rats. Toxicol Sci 77: 117-125.

85. Cui D, Tian F, Ozkan CS, Wang M, Gao H, et al. (2005) Effect of single wal carbon nanotubes on human HEK293 cells. Toxicology Letters 155: 73-85.

86. Montes-Fonseca SL, Orrantia-Borunda E, Aguilar-Elguezabal A, González Horta C, Talamás-Rohana P, et al. (2011) Cytotoxicity of functionalized carbon nanotubes in J774A macrophages. Nanomedicine.

87. Zhang L, Kiny VU, Peng H, Zhu J, Lobo RFM, et al. (2004) Sidewal functionalization of single-walled carbon nanotubes with hydroxyl groupterminated moieties. Chem mater 16: 2055-2061.

88. Hirsch A (2002) Functionalization of Single-Walled Carbon Nanotubes. Angew Chem Int Ed Engl 41: 1853-1859.

89. Pulikkathara M, Khabashesku V (2008) Covalent sidewall functionalization of single-walled carbon nanotubes by amino acids. Russian Chemical Bulletin 57 1054-1062.

90. Hirsch A, Vostrowsky O (2005) Functionalization of Carbon Nanotubes Functional Molecular Nanostructures. Springer Berlin / Heidelberg 193-237.

91. Georgakilas V, Kordatos K, Prato M, Guldi DM, Holzinger M, et al. (2002) Organic Functionalization of Carbon Nanotubes. J Am Chem Soc 124: 760761.

92. Ménard-Moyon C, Dumas F, Doris E, Mioskowski C (2006) Functionalization of single-wall carbon nanotubes by tandem high-pressure/ $\mathrm{Cr}(\mathrm{CO}) 6$ activation of Diels-Alder cycloaddition. J Am Chem Soc 128: 14764-14765.

93. Banerjee S, Hemraj-Benny T, Wong SS (2005) Covalent surface chemistry of single-walled carbon nanotubes. Advanced Materials 17: 17-29.

94. Lou X, Daussin R, Cuenot S, Duwez AS, Pagnoulle C, et al. (2004) Synthesis of pyrene-containing polymers and noncovalent sidewall functionalization of multiwalled carbon nanotubes. Chem Mater 16: 4005-4011.

95. Xue CH, Zhou RJ, Shi MM, Gao Y, Wu G, et al. (2008) The preparation of 
Citation: Jain S, Singh SR, Pillai S (2012) Toxicity Issues Related to Biomedical Applications of Carbon Nanotubes. J Nanomed Nanotechol 3:140. doi:10.4172/2157-7439.1000140

Page 14 of 15

highly water-soluble multi-walled carbon nanotubes by irreversible noncovalent functionalization with a pyrene-carrying polymer. Nanotechnology 19: 215604.

96. Nakashima N, Tomonari Y, Murakami H (2002) Water-soluble single-walled carbon nanotubes via noncovalent sidewall-functionalization with a pyrenecarrying ammonium ion. Chemistry Letters 31: 638-639.

97. Liu Z, Winters M, Holodniy M, Dai H (2007) siRNA delivery into human T cells and primary cells with carbon-nanotube transporters. Angew Chem Int Ed Engl 46: 2023-2027.

98. Liu Z, Davis C, Cai W, He L, Chen X, et al. (2008) Circulation and long-term fate of functionalized, biocompatible single-walled carbon nanotubes in mice probed by Raman spectroscopy. Proc Natl Acad Sci USA 105: 1410-1415.

99. Liu Z, Tabkman S, Welsher K, Dai H (2009) Carbon nanotubes in biology and medicine: In vitro and in vivo detection, imaging and drug delivery. Nano Research 2: 85-120.

100. Rungrotmongkol T, Arsawang U, lamsamai C, Vongachariya A, Dubas ST, et al. (2011) Increased dispersion and solubility of carbon nanotubes noncovalently modified by the polysaccharide biopolymer, chitosan:MD simulations. Chemical Physics Letters 507: 134-137.

101. Kam NWS, Liu Z, Dai H (2005) Functionalization of Carbon Nanotubes via Cleavable Disulfide Bonds for Efficient Intracellular Delivery of siRNA and Potent Gene Silencing. J Am Chem Soc 127: 12492-12493.

102. Xiao Y GX, Taratula O, Treado S, Urbas A, Holbrook RD, et al. (2009) Anti-HER2 IgY antibody-functionalized single-walled carbon nanotubes for detection and selective destruction of breast cancer cells. BMC Cancer 2: 351

103. Hu X, Cook S, Wang P, Hwang Hm, Liu X, et al. (2010) In vitro evaluation of cytotoxicity of engineered carbon nanotubes in selected human cell lines. Science of The Total Environment 408: 1812-1817.

104. Casey A, Herzog E, Lyng FM, Byrne HJ, Chambers G, et al. (2008) Single walled carbon nanotubes induce indirect cytotoxicity by medium depletion in A549 lung cells. Toxicol Lett 179: 78-84.

105. Monteiro-Riviere NA, Inman AO (2006) Challenges for assessing carbon nanomaterial toxicity to the skin. Carbon 44: 1070-1078.

106. Ema M, Matsuda A, Kobayashi N, Naya M, Nakanishi J, et al. (2011) Evaluation of dermal and eye irritation and skin sensitization due to carbon nanotubes. Regul Toxicol Pharmacol 61: 276-281.

107. Murray AR, Kisin E, Leonard SS, Young SH, Kommineni C, et al. (2009) Oxidative stress and inflammatory response in dermal toxicity of single-walled carbon nanotubes. Toxicology 257: 161-171.

108. Rouse JG, Yang J, Barron AR, Monteiro-Riviere NA (2006) Fullerene-based amino acid nanoparticle interactions with human epidermal keratinocytes. Toxicology In Vitro 20: 1313-1320.

109. Saathoff JG, Inman AO, Xia XR, Riviere JE, Monteiro-Riviere NA, et al. (2011) In vitro toxicity assessment of three hydroxylated fullerenes in human skin cells. Toxicology In Vitro 25: 2105-2112.

110. Prow TW, Grice JE, Lin LL, Faye R, Butler M, et al. (2011) Nanoparticles and microparticles for skin drug delivery. Adv Drug Deliv Rev 63: 470-491.

111. Shvedova AA, Kisin ER, Porter D, Schulte P, Kagan VE, et al. (2009) Mechanisms of pulmonary toxicity and medical applications of carbon nanotubes: Two faces of Janus?. Pharmacol Ther 121: 192-204.

112. Kayat J, Gajbhiye V, Tekade RK, Jain NK (2011) Pulmonary toxicity of carbon nanotubes: a systematic report. Nanomedicine 7: 40-49.

113. Ellinger-Ziegelbauer $\mathrm{H}$, Pauluhn J (2009) Pulmonary toxicity of multi-walled carbon nanotubes relative to $\alpha$-quartz following a single inhalation exposure of rats and a 3 months post-exposure period. Toxicology 266: 16-29.

114. Yuan Y, Wang X, Jia G, Liu JH, Wang T, et al. (2010) Pulmonary toxicity and translocation of nanodiamonds in mice. Diam Relat Mater 19: 291-299.

115. Yang ST, Wang X, Jia G, Gu Y, Wang T, et al. (2008) Long-term accumulation and low toxicity of single-walled carbon nanotubes in intravenously exposed mice. Toxicol Lett 181: 182-189.

116. Belyanskaya L, Manser $P$, Spohn $P$, Bruinink A, Wick $P$, et al. (2007) The reliability and limits of the MTT reduction assay for carbon nanotubes-cell interaction. Carbon 45: 2643-2648.

117. Jain AK ,Lodhi N, Dube V, Mishra DK, Jain PK et al. (2007) Carbon nanotubes and their toxicity. Nanotoxicology 1: 167-197.

118. Oberdörster G, Elder A (2007) Metal particles and extrapulmonary transport oberdörster and elder respond. Environ Health Perspect 115: A70-A71

119. Marilyn FH, Pam G, Lou D, Kallin D (2009) Potential risks of nanomaterials and how to safely handle materials of uncertain toxicity. Journal of Chemical Health \& Safet 16: 16-23.

120. Chou CC, Hsiao HY, Hong QS, Chen CH, Peng YW, et al. (2008) Singlewalled carbon nanotubes can induce pulmonary injury in mouse model. Nano Letters 8: 437-445.

121. Anna A, Shvedova ERK, Robert M, Ashley R, Murray V, et al. (2005) Unusual inflammatory and fibrogenic pulmonary responses to single-walled carbon nanotubes in mice. Am J Physiol-Lung Cell Mol Physiol 289: L698-L708.

122. Oberdörster G, Sharp Z, Atudorei V, Elder A, Gelein R, et al. (2004) Translocation of inhaled ultrafine particles to the brain. Inhal Toxicol 16: 437445.

123. Lange AHH (2001) Carbon nanotubes: Experimental evidence for a null risk of skin irritation and allergy. Fullerene Science and Technology 9: 247-250.

124. Muller J, Huaux F, Moreau N, Misson P, Heilier JF, et al. (2005) Respiratory toxicity of multi-wall carbon nanotubes. Toxicol Appl Pharmacol 207: 221-231.

125. Smart SK, Cassady Al, Lu GQ, Martin DJ (2006) The biocompatibility of carbon nanotubes. Carbon 44: 1034-1047.

126. Doak SH, Manshian B, Jenkins GJS, Singh N (2011) In vitro genotoxicity testing strategy for nanomaterials and the adaptation of current OECD guidelines. Mutat Res 745: 104-111.

127. Kisin ER, Murray AR, Sargent L, Lowry D, Chirila M, et al. (2011) Genotoxicity of carbon nanofibers: Are they potentially more or less dangerous than carbon nanotubes or asbestos? Toxicol Appl Pharmacol 252: 1-10.

128. Lindberg HK, Falck GCM, Suhonen S, Vippola M, Vanhala E, et al. (2009) Genotoxicity of nanomaterials: DNA damage and micronuclei induced by carbon nanotubes and graphite nanofibres in human bronchial epithelial cells in vitro. Toxicol Lett 186: 166-173.

129. Naya M, Kobayashi N, Mizuno K, Matsumoto K, Ema M, et al. (2011) Evaluation of the genotoxic potential of single-wall carbon nanotubes by using a battery of in vitro and in vivo genotoxicity assays. Regul Toxicol Pharmacol 61: 192-198.

130. Wirnitzer U, Herbold B, Voetz M, Ragot J (2009) Studies on the in vitro genotoxicity of baytubes $\AA$, agglomerates of engineered multi-walled carbonnanotubes (MWCNT). Toxicol Lett 186: 160-165.

131. Kim J, Lee K, Lee YH, Cho HS, Kim KH, et al. (2011) Aspect ratio has no effect on genotoxicity of multi-wall carbon nanotubes. Archives of Toxicology 5: $775-786$

132. Lam CW, James JT, McCluskey R, Arepalli S, Hunter RL, et al. (2011) A review of carbon nanotube toxicity and assessment of potential occupationa and environmental health risks. Crit Rev Toxicol 36: 189-217.

133.Zhu L, Chang DW, Dai L, Hong Y (2007) DNA damage induced by multiwalled carbon nanotubes in mouse embryonic stem cells. Nano Letters 7: 3592-3597.

134. Takagi A, Hirose A, Nishimura T, Fukumori N, Ogata A, et al. (2008) Induction

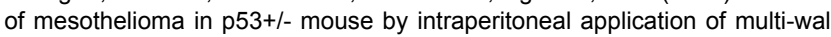
carbon nanotube. J Toxicol Sci 33: 105-116.

135. Karlsson HL, Cronholm P, Gustafsson J, Möller L (2008) Copper oxide nanoparticles are highly toxic: a comparison between metal oxide nanoparticles and carbon nanotubes. Chem Res Toxicol. 21: 1726-1732.

136. Haniu H, Matsuda Y, Takeuchi K, Kim YA, Hayashi T, et al (2011) Proteomicsbased safety evaluation of multi-walled carbon nanotubes. Toxicol Appl Pharmacol 242: 256-262.

137. Ruzer LS (2011) Exposure and Dose: Health Effect Studies Associated with Nanometer Aerosols. J Nanomed Nanotechnol 2: 120.

138.http://www.regulatorygovernance.ca

139. Simko M, Mattsson MO (2010) Risks from accidental exposures to engineered nanoparticles and neurological health effects: A critical review. Part Fibre Toxicol 7: 42 .

140. Jürgen $P$ (2010) Multi-walled carbon nanotubes (Baytubes ${ }^{\circledR}$ ): Approach fo 
Citation: Jain S, Singh SR, Pillai S (2012) Toxicity Issues Related to Biomedical Applications of Carbon Nanotubes. J Nanomed Nanotechol 3:140. doi:10.4172/2157-7439.1000140

derivation of occupational exposure limit. Regul Toxicol Pharmacol 57: 78-89.

141.http://discovermagazine.com/2009/jul-aug/21-future-tech-carbon-nanotubegrows-up-nanoyarn-kilometer-long

142.http://www.baytubes.com/news_and_services/pr_100223_heater.html

143.http://www.baytubes.com/news_and_services/pr_100813_kayak.html

144.http://www.nanotech-now.com/current-uses.html

145. Lynn KD, Weiss M, Naumov A, Bartholomeusz G, Bruce RW, et al. (2012) Carbon nanotubes: solution for the therapeutic delivery of siRNA. Materials 5: 278-301.

146. http://nano.cancer.gov/learn/now/clinical-trials.asp

147. Kagan VE, Konduru NV, Feng W, Allen BL, Conroy J, et al. (2010) Carbon nanotubes degraded by neutrophil myeloperoxidase induce less pulmonary inflammation. Nat Nanotechnol 5: 354-359.

148. Qin W, Yang K, Tang H, Tan L, Xie Q, et al. (2011) Improved GFP gene transfection mediated by polyamidoamine dendrimer-functionalized multi-walled carbon nanotubes with high biocompatibility. Colloids Surf B Biointerfaces 84: 206-213.

149. Coccini T, Roda E, Sarigiannis DA, Mustarelli P, Quartarone E, et al. (2010) Effects of water-soluble functionalized multi-walled carbon nanotubes examined by different cytotoxicity methods in human astrocyte D384 and lung A549 cells. Toxicology 269: 41-53.

150.Zhang F, Weidmann A, Nebe JB, Burkel E (2010) Osteoblast cell response to surface-modified carbon nanotubes. Materials Science and Engineering: C 32: 1057-1061.

151. Cai D, Mataraza JM, Qin ZH, Huang Z, Huang J, et al. (2005) Highly efficient molecular delivery into mammalian cells using carbon nanotube spearing. Nat Methods 2: 449-454.

152. Ahmed M, Jiang X, Deng Z, Narain R (2009) Cationic glyco-functionalized single-walled carbon nanotubes as efficient gene delivery vehicles. Bioconjug Chem 20: 2017-2022.

153. Singh R, Pantarotto D, McCarthy D, Chaloin O, Hoebeke J, et al. (2005) Binding and condensation of plasmid DNA onto functionalized carbon nanotubes: towards the construction of nanotube -based gene delivery vectors. J Am Chem Soc. 127: 4388-4396.

154.Dumortier H, Lacotte S, Pastorin G, Marega R, Wu W, et al. (2006) Functionalized carbon nanotubes are non-cytotoxic and preserve the functionality of primary immune cells. Nano Letters 6: 1522-1528.

155. Sayes CM, Liang F, Hudson JL, Mendez J, Guo W, et al. (2006) Functionalization density dependence of single-walled carbon nanotubes cytotoxicity in vitro. Toxicol Lett 161: 135-142.

156. Bardi G, Tognini P, Ciofani G, Raffa V, Costa M, et al. (2009) Pluronic-coated carbon nanotubes do not induce degeneration of cortical neurons in vivo and in vitro. Nanomedicine : Nanotechnology, Biology, and Medicine 5: 96-104.

157. Monteiro-Riviere NA, Inman AO, Wang YY, Nemanich RJ (2005) Surfactant effects on carbon nanotube interactions with human keratinocytes. Nanomedicine: Nanotechnology, Biology and Medicine 1: 293-299.

158. Vuković G, Marinković A, Obradović M, Radmilović V, Čolić M, et al. (2009) Synthesis, characterization and cytotoxicity of surface amino-functionalized water-dispersible multi-walled carbon nanotubes. Applied Surface Science 255: 8067-8075.

159. Gao L, Nie L, Wang T, Qin Y, Guo Z, et al. (2006) Carbon nanotube delivery of the GFP gene into mammalian cells. Chembiochem 7: 239-242.

160.Zhang LW, Zeng L, Barron AR, Monteiro-Riviere NA (2007) Biological interactions of functionalized single-wall carbon nanotubes in human epidermal keratinocytes. Int J Toxicol. 26: 103-113.

161.Liu Y, Wu DC, Zhang WD, Jiang X, He CB, et al. (2005) Polyethyleniminegrafted multiwalled carbon nanotubes for secure noncovalent immobilization and efficient delivery of DNA. Angew Chem Int Ed Engl 44: 4782-4785.

162. Schipper ML, Nakayama-Ratchford N, Davis CR, Kam NWS, Chu P, et al. (2008) A pilot toxicology study of single-walled carbon nanotubes in a small sample of mice. Nat Nano 3: 216-221.

163. Azizian J, Tahermansouri H, Biazar E, Heidari S, Khoei DC (2010) Functionalization of carboxylated multiwall nanotubes with imidazole derivatives and their toxicity investigations. Int J Nanomedicine 5: 907-914.
164.Guo J, Zhang X, Li Q, Li W (2007) Biodistribution of functionalized multiwall carbon nanotubes in mice. Nuclear medicine and biology 34: 579-583.

165. Wu Z, Feng W, Feng Y, Liu Q, Xu X, et al. (2007) Preparation and characterization of chitosan-grafted multiwalled carbon nanotubes and their electrochemical properties. Carbon 45: 1212-1218.

166. Tang C, Zhou T, Yang J, Zhang Q, Chen F, et al. (2011) Wet-grinding assisted ultrasonic dispersion of pristine multi-walled carbon nanotubes (MWCNTs) in chitosan solution. Colloids Surf B: Biointerfaces 86: 189-197.

167. Jain AK, Dubey V, Mehra NK, Lodhi N, Nahar M, et al. (2009) Carbohydrateconjugated multiwalled carbon nanotubes: development and characterization. Nanomedicine : Nanotechnology, Biology, and Medicine 5: 432-442.

168. Qiu J, Wang GJ (2008) Comparative study on modification of multi-walled carbon nanotubes by a hydrophilic polymer with different approaches. Applied Surface Science 254: 5691-5694.

169.Wu TM, Chang HL, Lin YW (2009) Synthesis and characterization of conductive polypyrrole/multi-walled carbon nanotubes composites with improved solubility and conductivity. Compos Sci Technol 69: 639-644.

170. Meuer S, Braun L, Schilling T, Zentel R (2009) a-Pyrene polymer functionalized multiwalled carbon nanotubes: Solubility, stability and depletion phenomena. Polymer 50: 154-160.

171.Luan J, Zhang A, Zheng Y, Sun L (2012) Effect of pyrene-modified multiwalled carbon nanotubes on the properties of epoxy composites. Composites Part A: Applied Science and Manufacturing 43: 1032-1037.

172. Farbod M, Tadavani SK, Kiasat A (2011) Surface oxidation and effect of electric field on dispersion and colloids stability of multiwalled carbon nanotubes. Colloids Surf A: Physicochem Eng Asp 384: 685-690.

173. Luo Y, Zhao Y, Cai J, Duan Y, Du S (2012) Effect of amino-functionalization on the interfacial adhesion of multi-walled carbon nanotubes/epoxy nanocomposites. Materials \& Design 33: 405-412.

174. Liu M, Yang Y, Zhu T, Liu Z (2005) Chemical modification of single-walled carbon nanotubes with peroxytrifluoroacetic acid. Carbon 43: 1470-1478.

175. Ahmad MN, Xie JY, Ma YH, Yang WT (2010) Surface functionalization of single-walled carbon nanotubes using photolysis for enhanced dispersion in an organic solvent. New Carbon Materials 25: 134-140.

176. Wan J, Yan X, Ding J, Ren R (2010) A simple method for preparing biocompatible composite of cellulose and carbon nanotubes for the cell sensor. Sens Actuators B: Chem 146: 221-225.

177. Islam MF, Rojas E, Bergey DM, Johnson AT, Yodh AG (2003) High weight fraction surfactant solubilization of single-wall carbon nanotubes in water Nano Letters 3: 269-273.

178. Yurekli K, Mitchell CA, Krishnamoorti R (2004) Small-angle neutron scattering from surfactant-assisted aqueous dispersions of carbon nanotubes. $\mathrm{J} \mathrm{Am}$ Chem Soc 126: 9902-9903.

179. Chen R, Zhang Y, Wang D, Dai H (2001) Noncovalent sidewall functionalization of single-walled carbon nanotubes for protein immobilization. J Am Chem Soc 123: 3838-3839. 